\title{
The Creation of the Sixteenth-century Architectural Ensemble at the Solovetskii-Transfiguration Monastery
}

\author{
William C. Brumfield* \\ Tulane University \\ New Orleans, Louisiana, USA
}

Received 09.04.2016, received in revised form 11.06.2016, accepted 21.08.2016

This article examines the major sixteenth-century architectural monuments of Solovetskii Transfiguration Monastery, with particular emphasis on the Preobrazhenskii sobor. Through the impetus provided by an exceptionally gifted and dynamic hegumen, Filipp, the monastery was able during the latter half of the sixteenth century to acquire the technical and physical resources necessary to initiate major building projects. The origins of this extraordinary architectural achievement can be attributed to a culturally and politically complex "triad" formed by the Novgorod eparchy, the Muscovite court, and the already substantial monastic centers of northern Russian culture. Although the monastery appears strikingly unusual, many of the architectural elements are found either in Novgorodian or in Muscovite precursors. The text and accompanying photographs (based on the author's fieldwork) define the architectural forms, their possible origins, and their historical context.

Keywords: Solovetskii Transfiguration Monastery, 16th-century Russian church architecture, Novgorod, Moscow, Ivan IV (the Terrible), White Sea, Filipp (Kolychev), St. Zosima, St. Savvatii, Livonian war.

DOI: 10.17516/1997-1370-2016-9-9-2231-2259.

Research area: theory and history of culture.

In the territory of the Russian north, no place carries more historical weight than the Transfiguration Monastery on Great Solovetskii Island, part of an archipelago strategically located near the Onega Peninsula in the southwestern part of the White Sea. ${ }^{1}$ Throughout the latter half of the sixteenth century the monastery was able to acquire the technical and physical resources necessary to initiate major building projects, including its massive stone walls. The impetus for this development originated with a gifted and dynamic hegumen, Filipp, the future metropolitan of the Russian church and, ultimately, the victim of a confrontation with Ivan the Terrible. By virtue of support from sources in Novgorod and other northern towns, as well as from Moscow, Filipp embarked on an ambitious program of construction and amelioration that transformed

(C) Siberian Federal University. All rights reserved

* Corresponding author E-mail address: william.brumfield@gmail.com 
much of Solovetskii Island over the next eighteen years.

Filipp not only greatly enhanced the economic viability of the monastery, he also created monumental buildings of stone and brick such as the Refectory Church of the Dormition and Cathedral of the Transfiguration of the Savior (Spaso-Preobrazhenskii Sobor), among the most interesting examples of late medieval architecture in Russia (Fig. 1). In the words of Olga Savitskaia, a leading specialist in the restoration of this monument: "In the Solovetskii temple (khram) everything is unusual: the exterior form, the interior structure of the spatial composition, the details of the architectural and construction elements." 2

Yet despite the unusual appearance of Transfiguration Monastery, many of its architectural elements are found either in Novgorodian or in Muscovite precursors. Therefore, an examination of the major sixteenth-century architectural monuments of the Solovetskii Transfiguration Monastery must also note the origins of this extraordinary architectural achievement in a culturally and politically complex «triad» formed by the Novgorod eparchy, the Muscovite court, and the already substantial monastic centers of northern Russian culture.

The architectural traditions of Novogord, which originated in the eleventh century and were among the most important in Kievan Rus, had a formative influence on northern monastic architecture. Yet by the sixteenth century Novgorod builders had entered into a period of interaction with Moscow's own rapidly developing church architecture, which in turn owed much to the Italian design and technology of brick construction imported to Moscow in the late fifteenth and early sixteenth centuries. It can be argued that the sixteenth-century monuments of the Solovetskii Monastery were derived from a combination of Muscovite and Novgorodian architectural techniques at a time when Novgorod's masonry architecture was evolving under the impact of Moscow's increasing presence.

There is evidence that the Solovetskii archipelago was settled, or visited, by humans

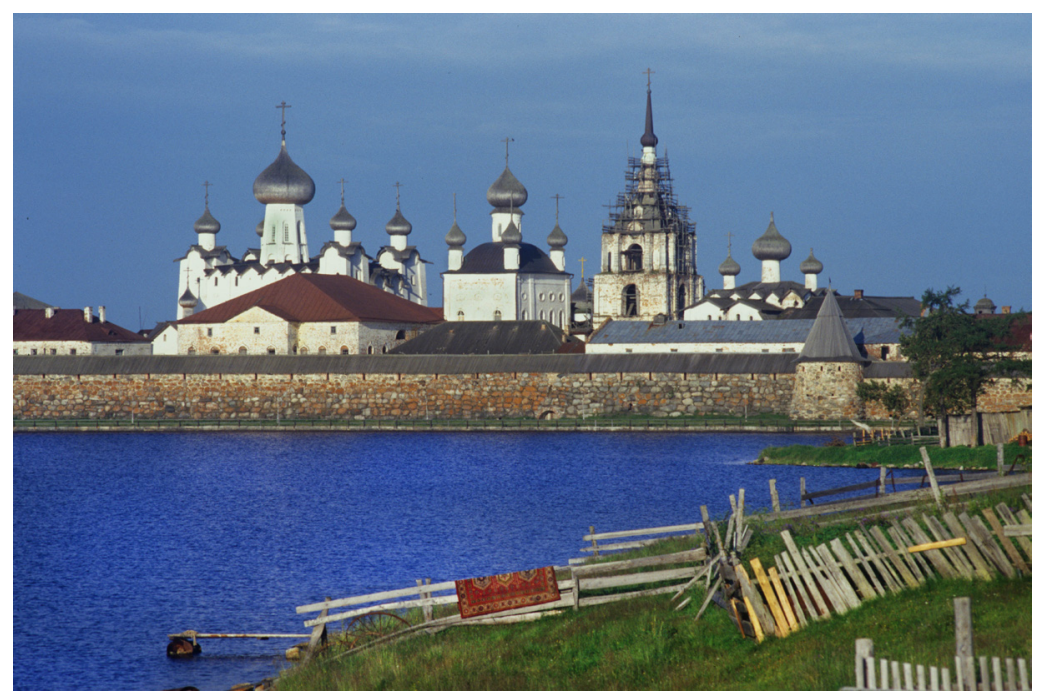

Fig. 1. Solovetskii Transfiguration Monastery. Northeast view across Holy Lake. From left: Transfiguration Cathedral, Cathedral of the Trinity and Sts. Zosima and Savvatii, Church of St. Nicholas, bell tower, Church of the Dormition. Photo: 1998. All photographs by the author 
as early as four millennia ago. ${ }^{3}$ The stone cairns and labyrinths on Large Solovetskii and Large Zaiatskii Islands indicate that the archipelago probably existed as sacred space long before the coming of Christian monks. Whatever the prehistoric rituals observed on the Solovetskii Islands, it was Russian Orthodoxy that defined the transformation of natural to spiritual when the early monks dedicated their first church on the island to the Transfiguration of the Savior, the miraculous expression of divine illumination and revelation. As one approaches the passage to the Bay of Felicity, the monastery seems to rise from the water, Grad Kitezh, a floating citadel of towers and domes (Fig. 2). ${ }^{4}$

Not until the early fifteenth century did the island chain attract the attention of a few hardy monks, part of a wave of monastic expansion throughout the Russian north in the late fourteenth and fifteenth centuries. The primary initiator of monastic presence on Solovetskii Island was the monk Savvatii, a pupil of the revered Kirill Belozerskii, who had founded on Siverskoe Lake one of the most active monasteries in the Russian north. After the death of Kirill, in 1427, Savvatii made his way to the monastic retreat on the Island of Valaam, in northern Lake Ladoga, but he eventually found it too crowded. ${ }^{5}$ Having heard of another island, in the White Sea, Savvatii ventured into the northeast, beyond Lake Onega and to the Karelian Shore.

There local inhabitants persuaded the elderly Savvatii to accept for this difficult venture one companion, an illiterate hermit named Herman (German), who had already visited Solovetskii Island. The generally accepted year of their first arrival on the island is 1429 , as stated in the Solovetskii chronicle, although Dmitrii Likhachev has argued for a slightly later date. ${ }^{6}$ The monks' endurance on the island was severely tested by the harsh winters and the lack of sufficient food. They only succeeded in growing small crops of turnips, and survival depended on the occasional arrival of promysloviki (primarily fishermen), as well as their own infrequent trips back to the mainland. During one such trip by German in 1435, Savvatii fell ill and made his own way to the mainland, where he soon thereafter died.

Savvatii's death brought an end to this first attempt at monastic settlement on Solovetskii Island. The following year, however, there appeared on the Karelian shore at the Suma River

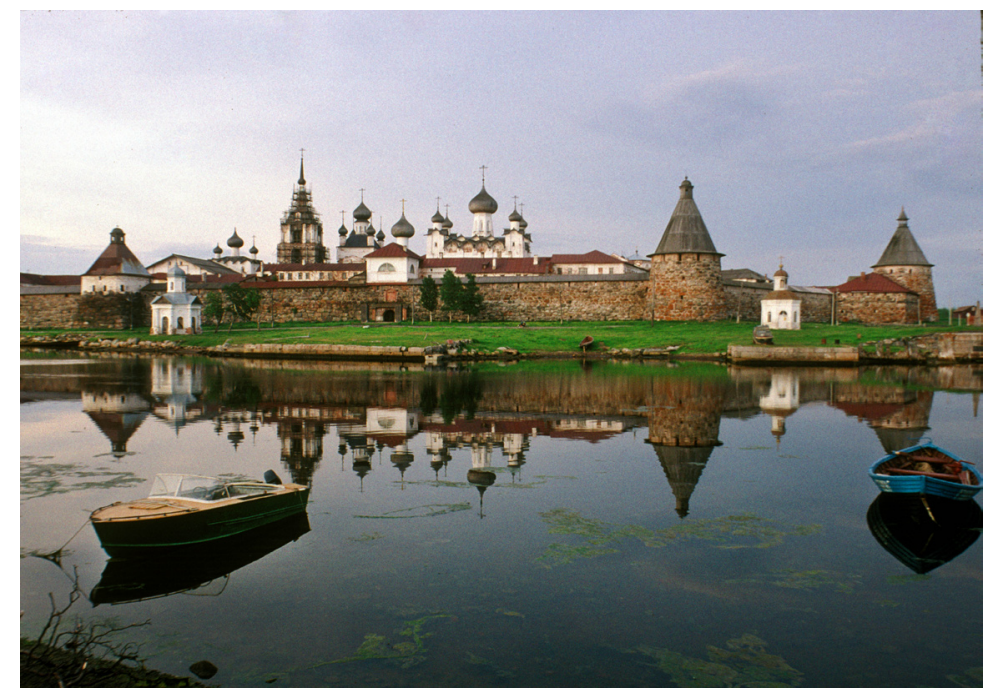

Fig. 2. Solovetskii Transfiguration Monastery. Southwest view across harbor. 1999 
another monk, Zosima, offspring of a prosperous Novgorodian merchant family from the area of Lake Onega. In 1436 Zosima and Herman returned to the island, where they settled on the present site of the monastery. Within a few years others joined them, the first log Church of the Transfiguration of the Savior was built, and the community came under the protection of the archbishop of Novgorod, who gave the monks title to the islands and sent a series of hegumens to the new monastery. They in turn received from Novgorodian merchants the first donations of land whose produce helped maintain the monastery. Thus began what would become an extensive system of mainland holdings that were used to support the monastery's various enterprises. After the departure of the first three hegumens sent from Novgorod, Zosima himself became hegumen in 1452 and served in that capacity until his death in $1478 .^{?}$

Coincidentally, that same year saw the subjugation of an independent Novgorod to Moscow, yet the monastery remained within the Novgorod eparchy, a fact of considerable significance foritsearly architecturaldevelopment. Aware of the strategic importance of this northern monastic outpost, the grand princes of Moscow reaffirmed the monks' title to the islands and their produce. During the first century of its existence, the monastery was built of wood, and it burned to the ground from lightning strikes on at least two occasions, in 1485 and $1538 .^{8}$ The inventory of 1549 lists among its basic structures three saltworks, three water mills, and three log churches: the Transfiguration of the Savior, with an additional altar to Saint Nicholas; the Church of the Dormition, with the monastic refectory; and the small Church of Saint Nicholas. ${ }^{9}$

The great flourishing of the monastery occurred in the middle of the sixteenth century under the energetic direction of Filipp (born Fedor; 1506-1569) Kolychev, a monk whose origins extended from a prominent Novgorod boiar family with extensive connections in Moscow. Kolychev left Moscow in the mid 1530s, joined the Solovetskii monastic community in 1537, and in 1548 became its hegumen. During that same period the Moscow sobor of 1547 had canonized Zosima and Savvatii, along with a number of other miracle-workers (chudotvortsy), as saints of all Russia. ${ }^{10}$ Filipp was particularly zealous in support of the canonization of Zosima and Savvatii, whom he extolled as exemplars of the monastic ideal in his successful campaigns to solicit donations for the Solovetskii monastery.

The earliest structure in this building campaign is the refectory Church of the Dormition (1552-1557), situated in the north part of the central monastic compound. It consists of a large refectory (trapeza) on the west and a twostory cuboid structure containing the church at the east end, all elevated over a ground floor, or podklet (Fig. 3, 4). The influence of Novgorod architecture on this design is obvious and by no means coincidental. Filipp had spent the winter of 1552 in Novgorod raising funds for his new buildings, and it is possible that he returned with the two Novgorod builders, Ignatii Salka and Stolypa, whose names appear in sources on the construction of the church. ${ }^{11}$

The Dormition Church itself occupies a relatively small portion in the southeast corner of the main structure, while the northeast part was occupied by the cellarer's chamber (Kelarskaia palata), itself an unusual structure with ceiling vaults converging on a single pier in the center (Fig. 5). (This device will be used to still more expansive effect in the refectory hall, discussed below.)

The upper part of the interior structure of the Dormition Church employs the blind vaulting typical of Novgorod architecture in the first half of the sixteenth century. Pentacupolar, open-vaulted churches were constructed in Novgorod in the first 


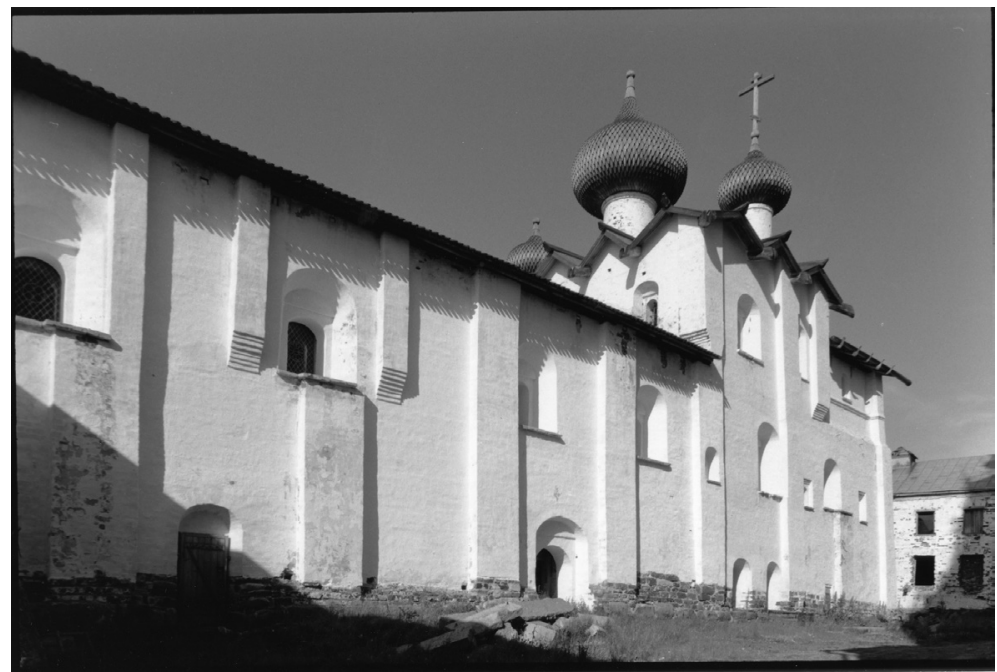

Fig. 3. Refectory and Church of the Dormition. South facade. 1999

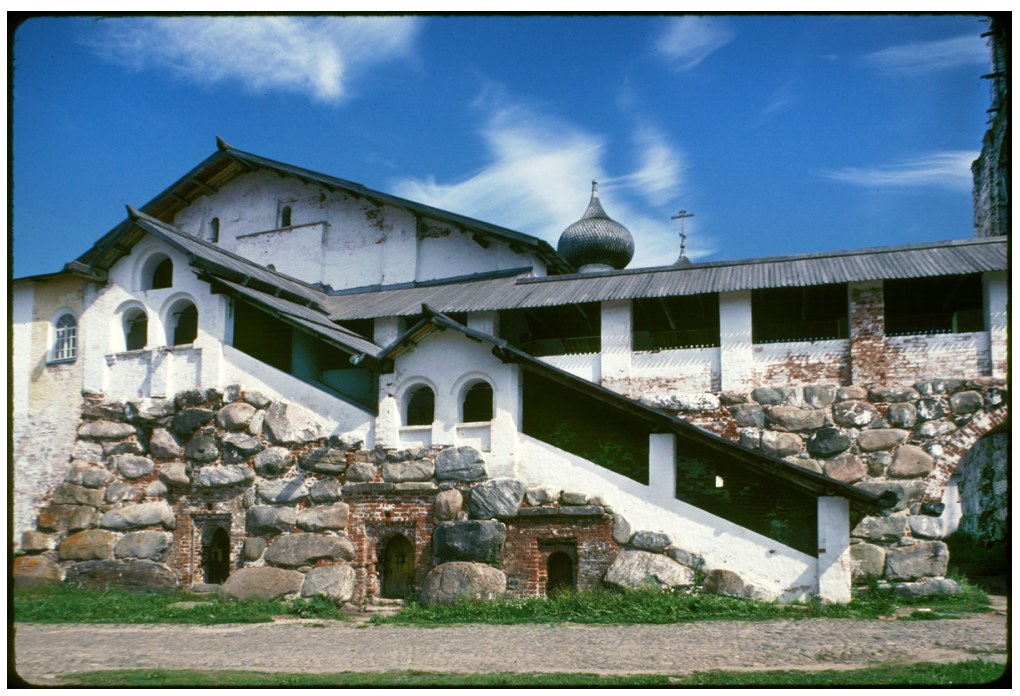

Fig. 4. Refectory and Church of the Dormition. West view. 1998

half of the sixteenth century, but these exceptions to fifteenth-century patterns of closed vaulting in Novgorod architecture can be explained by the influence of Moscow church architecture on Novgorod after 1478. One can assume that the "dialogue" between the church architecture of Moscow and Novgorod in the middle third of the sixteenth century intensified with the elevation of Makarii, archbishop of Novgorod from 1526, to the position of Metropolitan of All Russia in 1542 . For the sixteenth-century churches at
Solovetskii Monastery, however, specifically Novgorodian features play the greater role, ${ }^{12} \mathrm{As}$ a result the drums supporting the three exterior cupolas are also "blind": they do not admit light to the interior.

A further complexity is the presence over the apse of two additional altars (pridely). The first is to the Decapitation of John the Baptist, and the second, consecrated only in 1605 , is to Saint Dmitrii. ${ }^{13}$ Access to these altars was through a stairway built within the thick walls - one of 


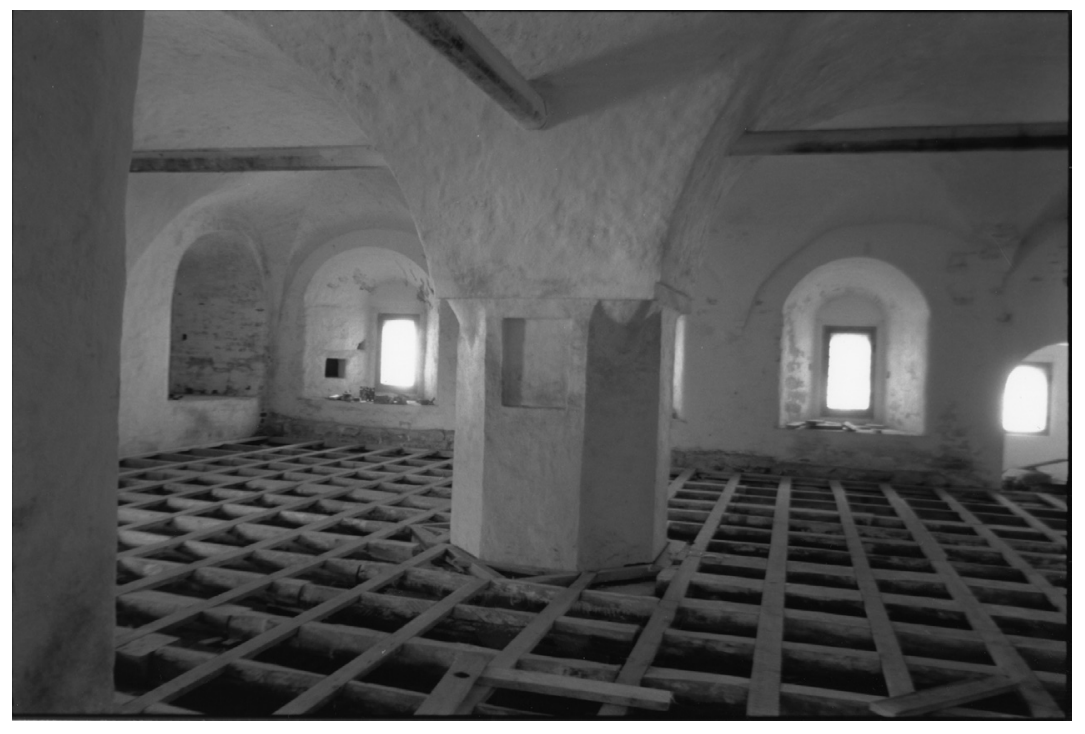

Fig. 5. Church of the Dormition. Cellarer's Hall (under restoration). 1998

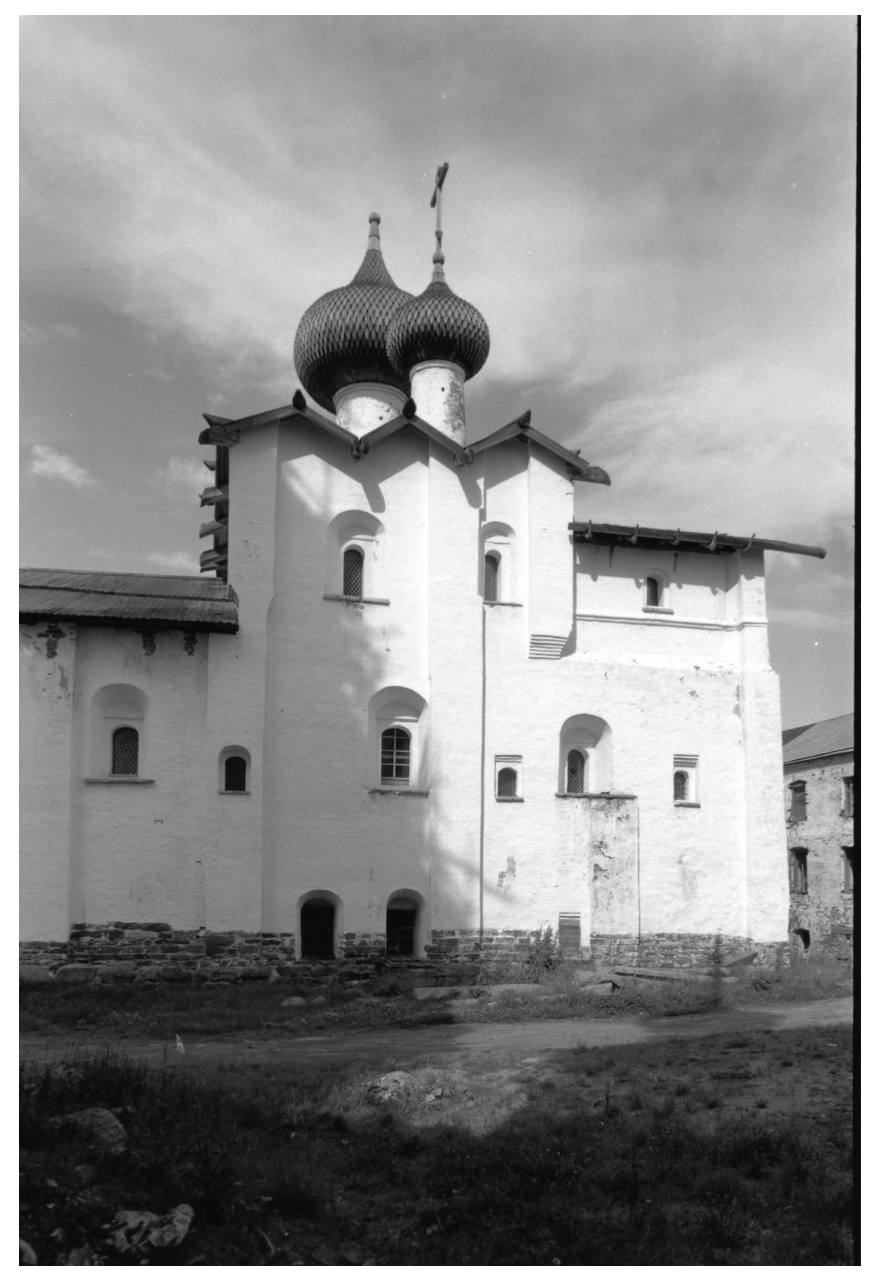

Fig. 6. Church of the Dormition. South view. 1999 
three such stairwells in the structure. On the west end the culminating point was a bell tower and wooden porch, reconstructed in the seventeenth century.

The exterior of the Dormition Church, with its compact form and decorative gables (Fig. 6), bears a still more visible resemblance to examples of contemporary Novgorod architecture, including the Church of the Trinity with refectory built at Novgorod's Holy Spirit Monastery in 1557 (Fig. 7), and the Church of the Annunciation on the Trading Side. ${ }^{14}$ The formal resemblance to the Trinity Church is particularly apposite not only because of the dates of construction but also because both share a distinctive roof design consisting of pointed kokoshniki (decorative gables), a wooden roof, and blind drums and cupolas that have an important symbolic role but play no part in the interior structure. Other similarities with Novgorod architecture include the construction of walls composed of fieldstone and brick (not to be confused with the Byzantine opus mixtum technique). ${ }^{15}$

Perhaps the most notable resemblance to a Novgorod prototype, however, occurs In the design of the refectory attached to the Dormition Church. This great hall (Fig. 8), whose vaulting rests in the center on a single pier, belongs to a group of such structures, of which the earliest is the krestovaia palata, part of the ensemble of

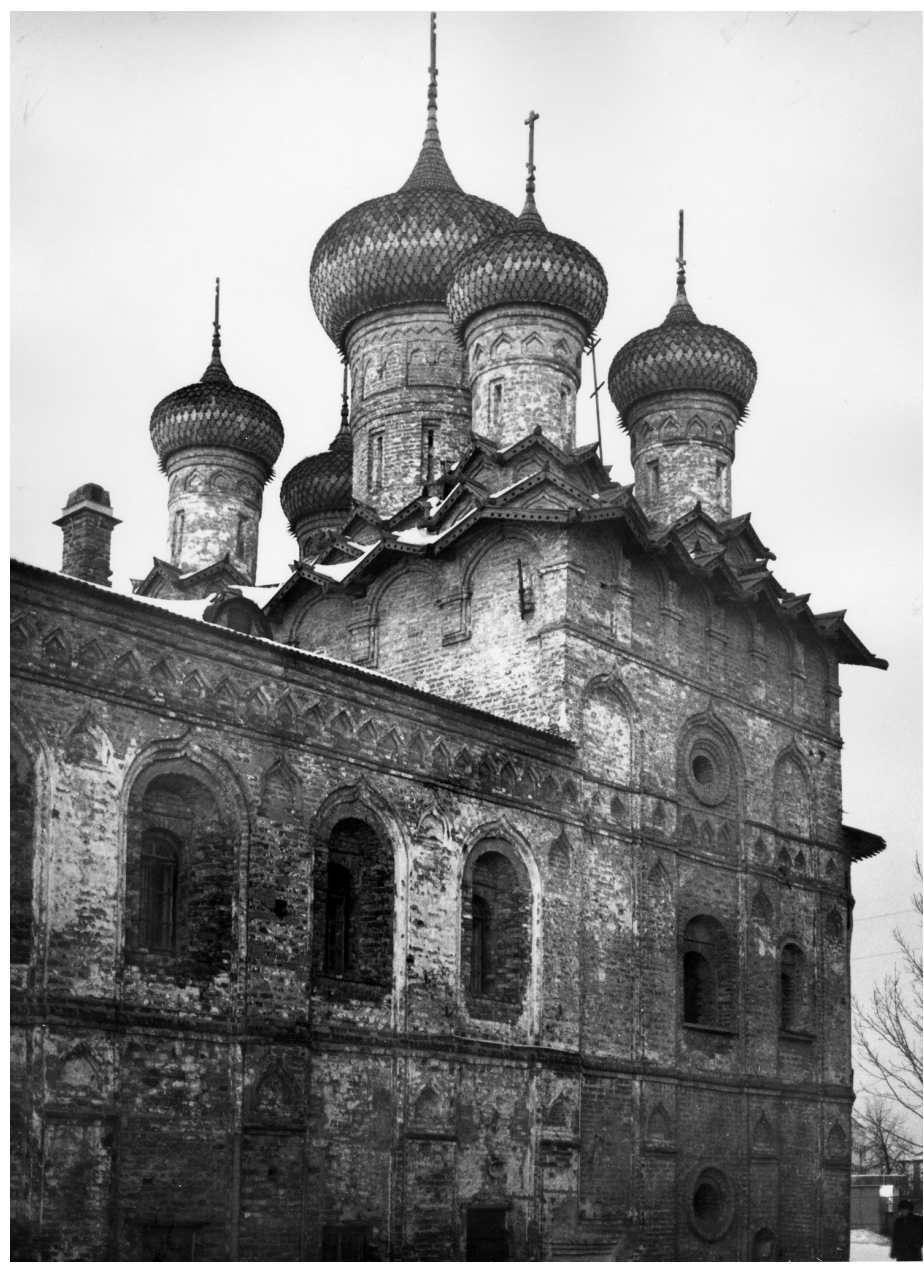

Fig. 7. Novgorod. Refectory Church of the Trinity, Holy Spirit Monastery. Southwest view. 1980 


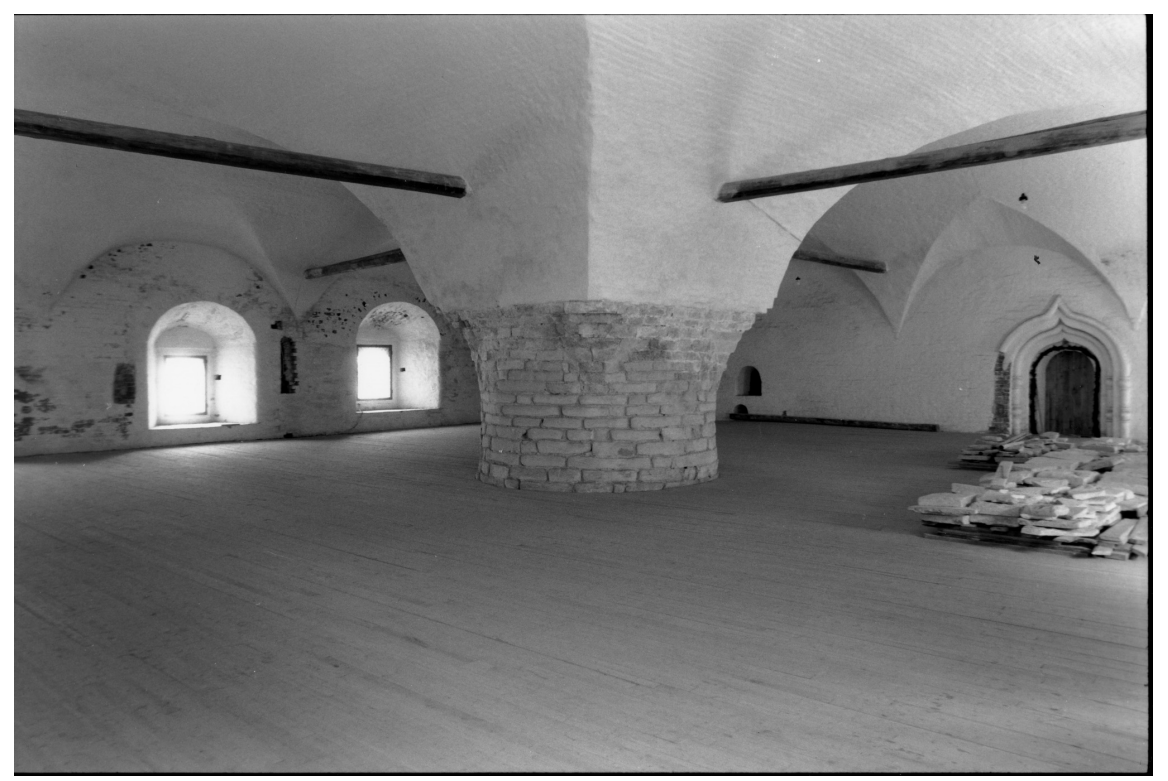

Fig. 8. Church of the Dormition. Refectory Hall. 1999

the Archbishop's Court in the Novgorod kremlin (ca. 1440). The name ("cross chamber") derives from the main vaulting structure, a cross vault. This form was widely used in the late Gothic architecture of northern Germany, with whom Novgorod had long had commercial relations, and it is possible that German masters in Novgorod not only supervised the construction but also introduced the term Kreuzgewolbe (cross vault) ${ }^{16}$ The next notable example of a singlepier hall in Russian architecture appeared in the Granovitaia palata (Moscow Kremlin), begun in 1487 by Marco Friazin and completed in 1491 by Pietro Antonio Solari. Here the main hall, which encompasses $459 \mathrm{~m} 2$, has four cross vaults converging on a single pier. ${ }^{17}$

Although similar in its basic design, the Solovetskii refectory is more archaic than either of the above halls, and, at $500 \mathrm{~m} 2$, it is also considerably larger. To sustain such an enormous weight, the central pier, or column - four meters in diameter and twelve in circumference - consists largely of cut stone, as do the wall abutments for the spans. This conceptually simple, but technically daring, system of vaults permitted a large area of the walls to be opened for window emplacements, thus allowing natural light for a space intended to accommodate as many as 250 for meals. 18 In addition to light, the refectory also needed a reliable and efficient source of heat. The Dormition Church, like other refectory churches in northern Russian monasteries, was designed with an effective system of heat transfer from the scullery, kitchen, and bakery on the ground floor (podklet) beneath the church and refectory. ${ }^{19}$

For all of the technical and design ingenuity of the refectory Dormition Church, Filipp had much larger things in mind. In any Russian Orthodox monastery the dominant point is its main church, or sobor, (cf. the concept of katholikon in Greek monasteries), the church whose dedication defines the monastery. Even as construction of the refectory church came to a conclusion in 1557 , Filipp had begun to collect the funds, including 1,000 rubles from grand prince Ivan Vasilevich (Ivan IV), for the rebuilding of the log Church of the Transfiguration of the Savior. Work began in 1558 , presumably guided by the same Novgorod builders Salka and Stolypa, and the sobor was completed in 1566. 
As the centerpiece of Filipp Kolychev's construction program at the monastery, the unique form of the Church of the Transfiguration has acquired almost mythic status. With the slight, but noticeable, incline of its massive walls, the Transfiguration Church seems a vision more appropriate to Lhasa than to Russia (Fig. 9). It represents the epitome of that ability of great monastery churches in Russia to dominate their surroundings, particularly with the vertical emphasis provided by the corner towers (Fig. 10). As Savitskaia has noted: "The system of culminating [the church] with corner tower projections, as well as a series of other no less essential details, imparts an entirely individual character to this monument." 20

Yet here, too, the form of the church derives from traditions, as well as innovations, in the sacred architecture of both Novgorod and Moscow. In defining the distinctive features and the antecedents of the Transfiguration Church, let us begin with the core of the design: the two massive piers at its center (Fig. 11). The middle of the sixteenth century was a time of bold experimentation in Russian architecture, and one of the results was the appearance of churches supported by two piers in the center of the structure, instead of the four central piers typical of inscribed-cross church plans in early medieval Russia. ${ }^{21}$ It has been argued that in "visual" terms the concept of the two-pier church had already surfaced in Novgorod in the latter half of the fourteenth century with the development of the high iconostasis, which in effect blocked the two eastern piers from view. ${ }^{22}$ One sees only the two western piers. This, together with innovations in masonry construction influenced by Italian masters in Moscow at the turn of the sixteenth century, let to the design of large two-pier churches.

Of these churches one of the most impressive is the Cathedral of the Annunciation (1560-early 1570s) at the Stroganov compound in Sol'vychegodsk (Fig. 12, 13). A comparison of the Sol'vychegodsk and Solovetskii sobory, under construction at the same time, reveals that the former has the greater symmetry: the two piers rise from the center of the structure and

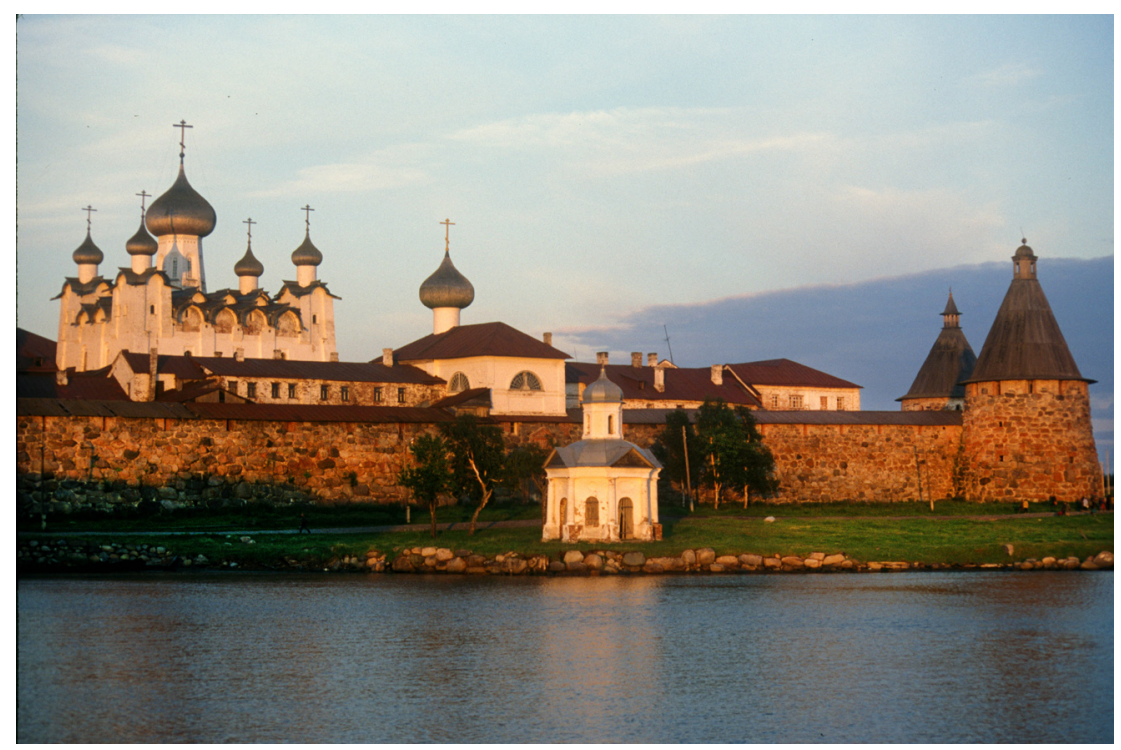

Fig. 9. Solovetskii Transfiguration Monastery. Northwest view across harbor. From left: Transfiguration Cathedral, Gate Church of the Annunciation, Chapel of St. Alexander, Spinning Tower. 1998 


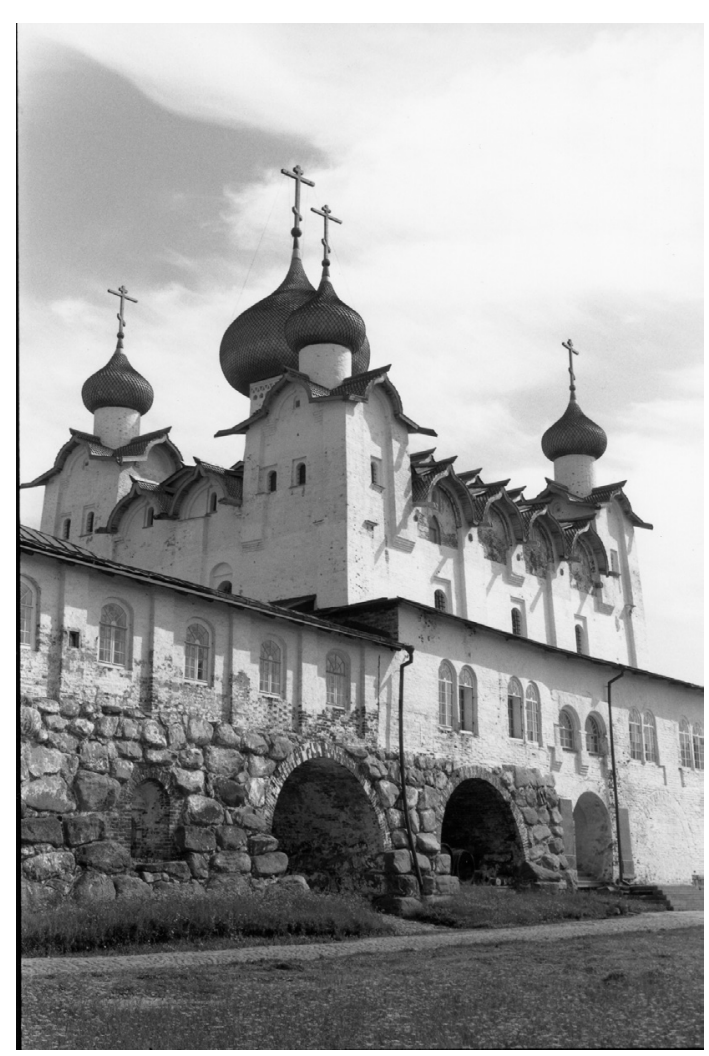

Fig. 10. Cathedral of the Transfiguration and gallery. Northwest view. 1998

support longitudinal arches that spring out to the east and west walls (Fig. 14). ${ }^{23}$ This device creates an interlocking system of barrel vaults that supports the roof and its five cupolas, all of which admit light - as one would expect in large Muscovite churches of this period. The main drum (baraban) and cupola rest on abutments directly above the two piers. This resolution not only establishes an clearly visible symmetry, but also creates an unusually open, well-illuminated central space.

ThebuildersoftheSolovetskiiTransfiguration Church, by contrast, placed two massive piers much larger than those at Sol'vychegodsk - in the center of the structure (cf. Fig. 11), and shifted the main drum to the east, where it rests between the piers and the east wall. (As at Sol'vychegodsk, the east wall also provides the support for the iconostasis.) Because of the large size of the piers

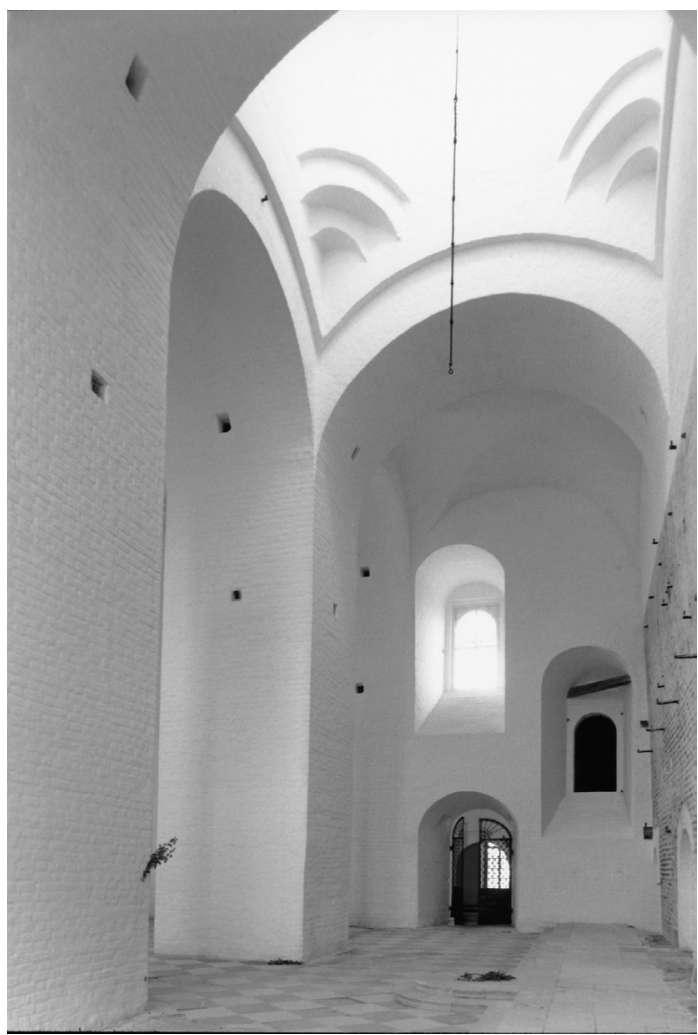

Fig. 11. Cathedral of the Transfiguration. Interior, view north. 1999.

and the smaller area given to window openings within the massive outer walls (approximately two meters thick), the interior of the Solovetskii church is darker than that of the Sol'vychegodsk Annunciation Cathedral. However, the area in front of the iconostasis is well illuminated by light from the windows of the drum beneath the main cupola.

Beyond the east wall is a large, rectangular apse, instead of the more traditional curved apsidal structure. ${ }^{24}$ Although less than half the height of the main structure, the apse is spacious enough to contain the main altar, dedicated to the Transfiguration, at the center of the apse, as well as two additional altars: one on the north side, dedicated to the monastery founders, Zosima and Savvatii; and one in the south part dedicated to the sword-bearing Archangel Michael, defender of the faith. The north altar was consecrated on 


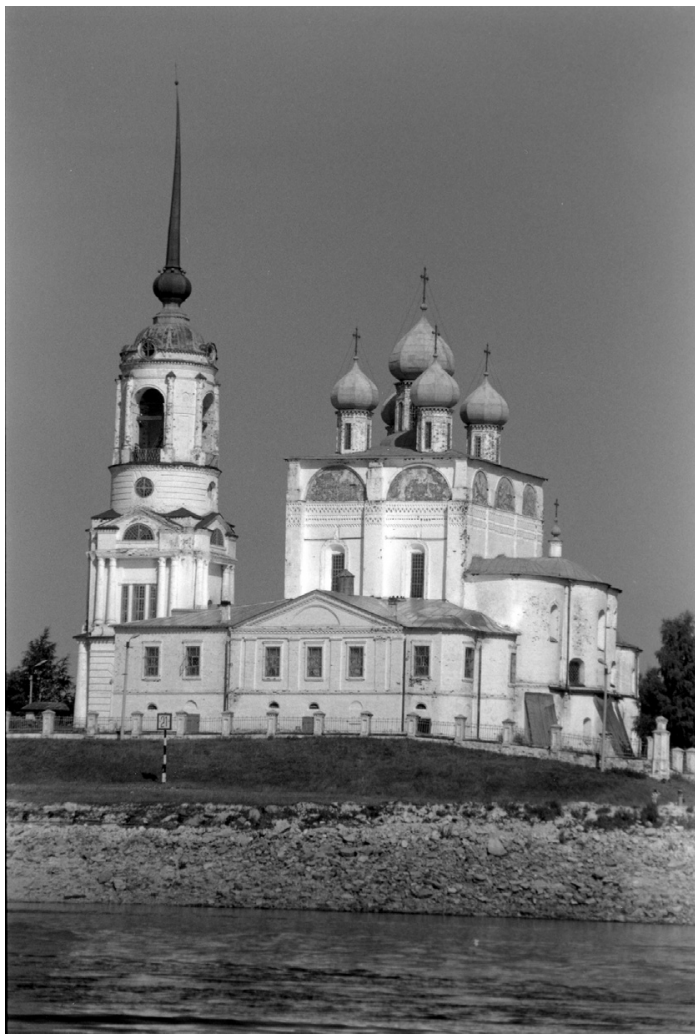

Fig. 12. Solvychegodsk. Cathedral of the Annunciation, southeast view from Vychegda River. 1999

August 6, 1566 (the festival of the Transfiguration in the old calendar), when the relics of Saints Zosima and Savvatii were solemnly placed therein. ${ }^{25}$ Slightly more than two decades later, in 1591, the remains of Filipp would join them in the crypt. ${ }^{26}$

The upper part of the Transfiguration Church is perhaps the most complex part of the structure. In all but one of the interior bays, the upper vaulting follows the Novgorod practice of closed (or blind) cross vaults. ${ }^{27}$ The one open bay encompasses the main drum and cupola, which rise from corbelled arches attached to spring arches that in turn connect the main piers and east wall (Fig. 15). The structural logic here is clear and poised.

The original form of the drum, however, has been much debated. The existing octagonal drum, with facets leading inward, is clearly the original

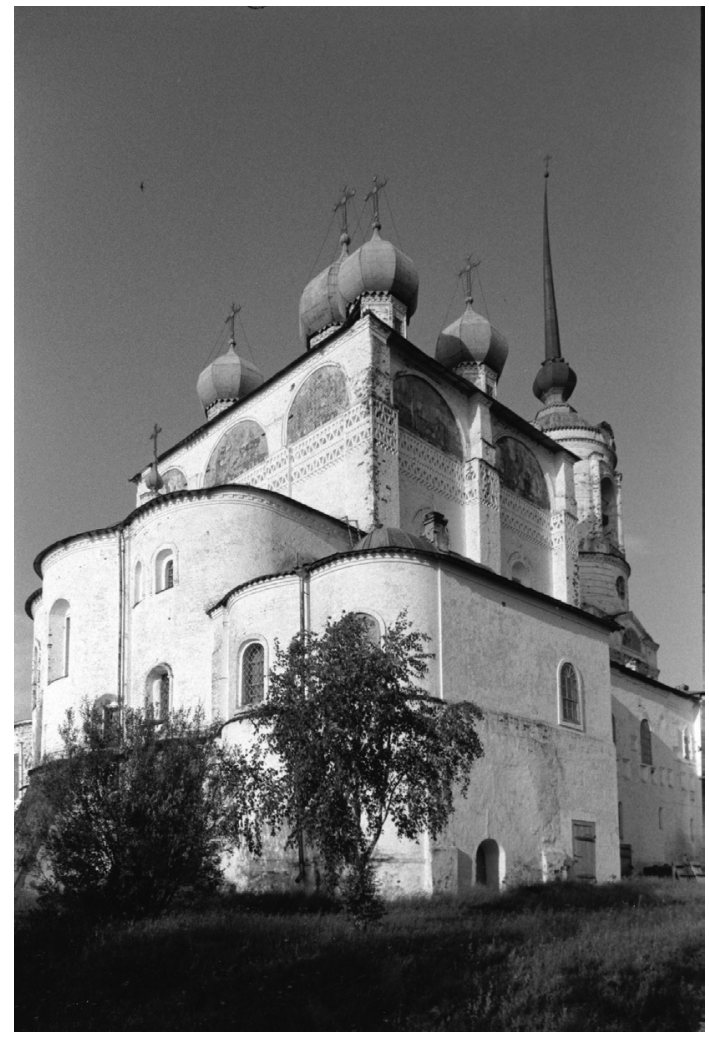

Fig. 13. Solvychegodsk. Cathedral of the Annunciation, northeast view. 1999

brickwork (Fig. 16). Yet some specialists have argued that this is only the first tier of a design that originally culminated in a tent tower (shatior) perhaps twice the height of the present drum. The evidence for this assumption is largely derived from stylized representations of the cathedral in miniatures and icons of Saints Zosima and Savvatii dating from the end of the sixteenth century and the first half of the seventeenth century (Fig. 17). ${ }^{28}$ In these images the Transfiguration Church is portrayed with a central tent tower reminiscent of two of the most notable monuments of sixteenthcentury Muscovite architecture: the Church of the Ascension at Kolomenskoe (1529-32; Fig. 18) and the Cathedral of the Intercession of the Virgin on the Moat, popularly known as Saint Basil's (1555-61). ${ }^{29}$ Some proponents of this view have argued that the missing upper tier, perhaps built of wood, could have been destroyed as a result of 


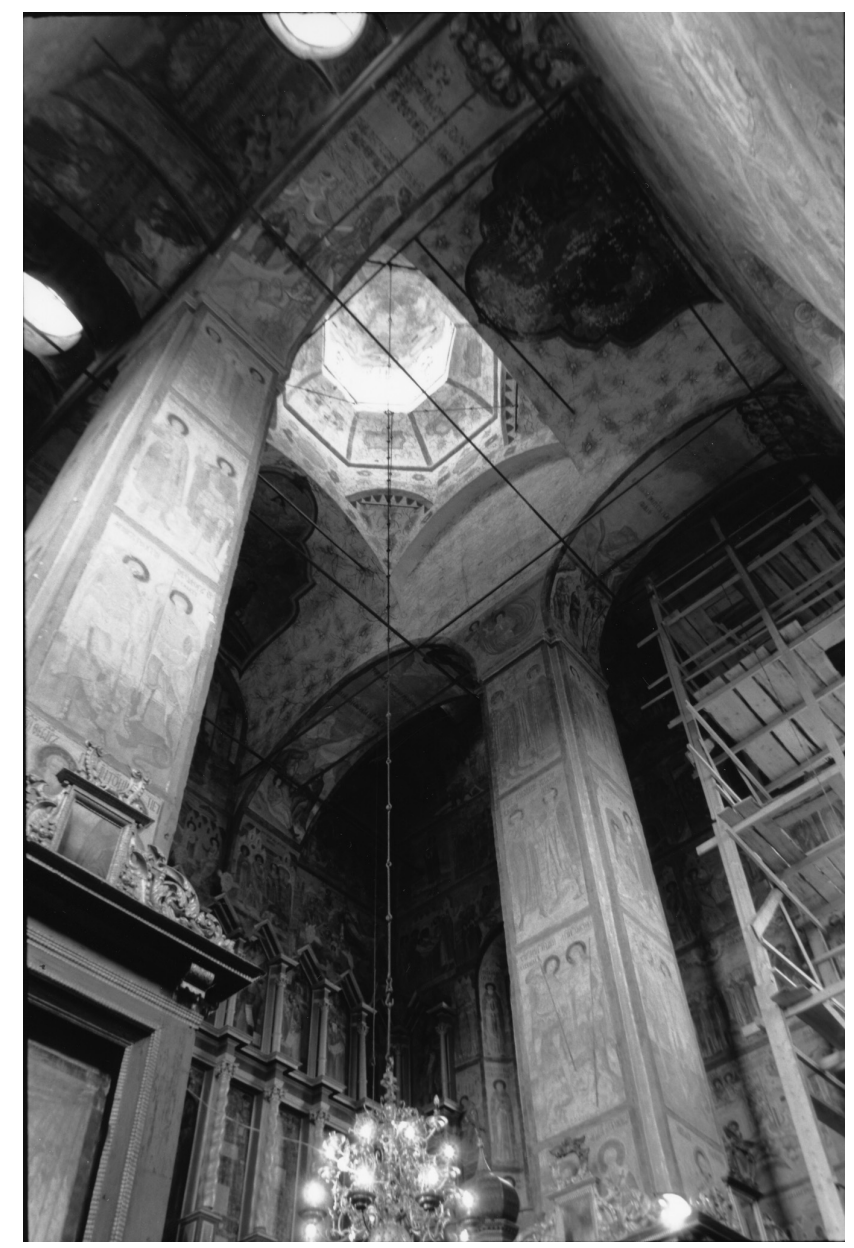

Fig. 14. Solvychegodsk. Cathedral of the Annunciation, interior, piers under main dome. 1996

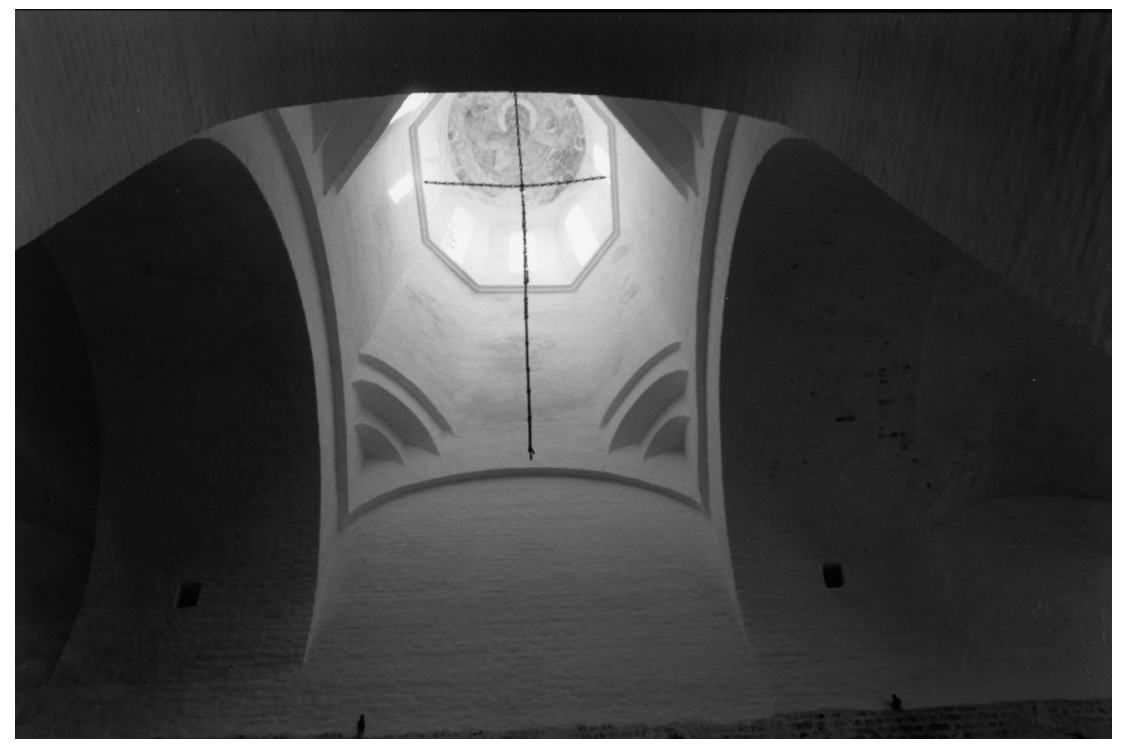

Fig. 15. Cathedral of the Transfiguration. Interior, main dome and east wall. 1999 


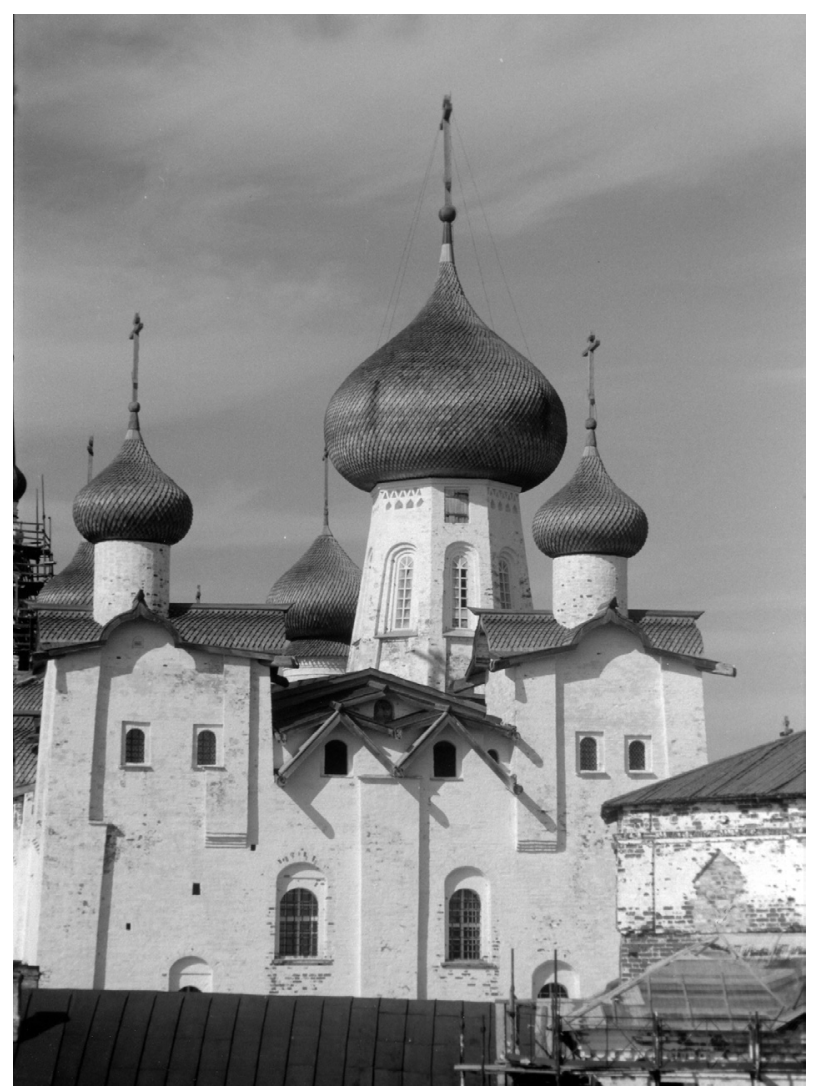

Fig. 16. Cathedral of the Transfiguration. South facade, upper tier. 1999

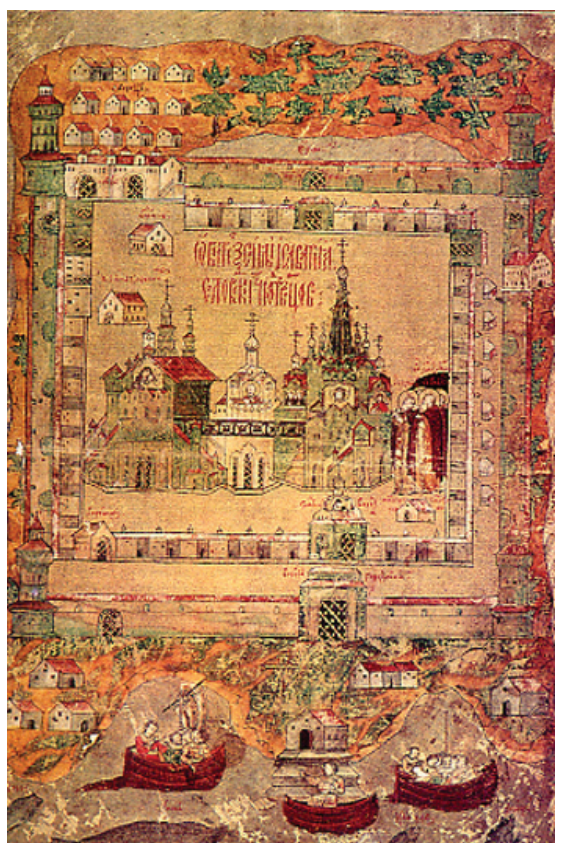

Fig. 17. Manuscript illumination of the Transfiguration Cathedral at Solovetskii Monastery, turn of 17th century. From Vakhrameev Vita of Saints Zosima and Savvatii 


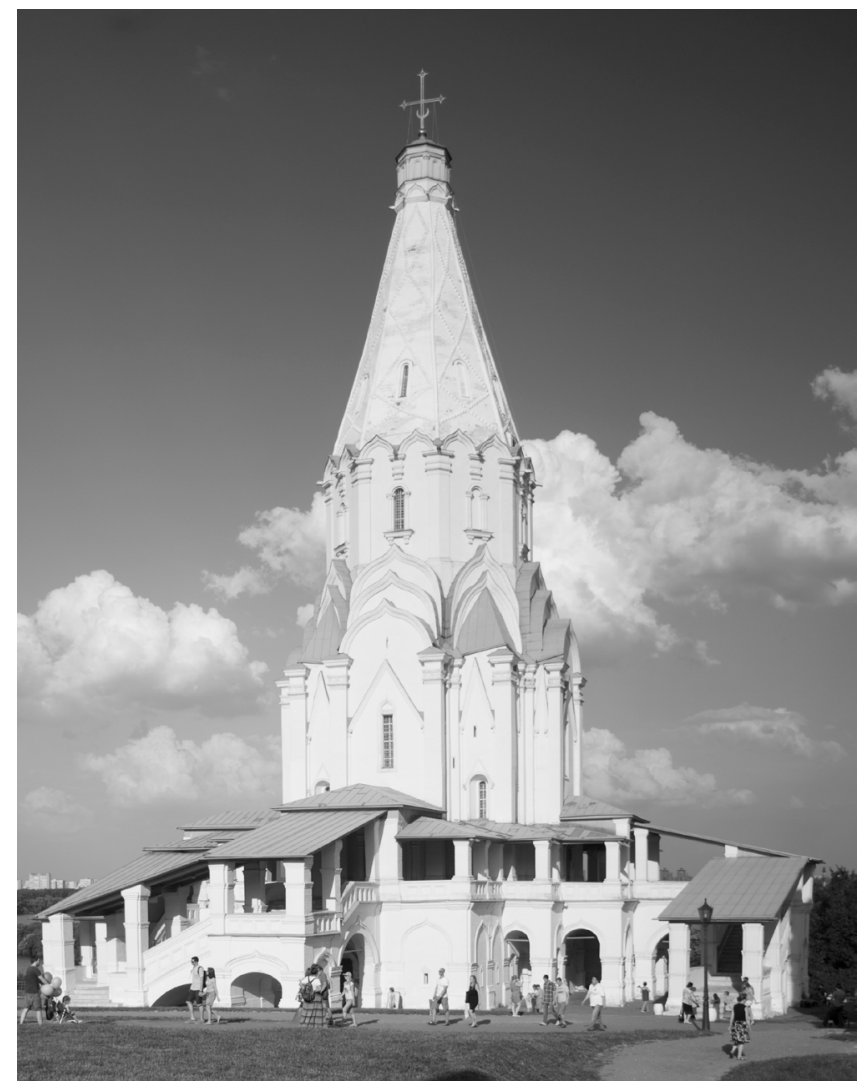

Fig. 18. Moscow. Church of the Ascension at Kolomenskoe, southwest view. 2014

bombardment during the long "Solovetskii Siege" or dismantled after the capture of the monastery in deference to the Nikonian ban against the shatior on the structure of the Orthodox church. ${ }^{30}$

The argument in favor of the existence of a tent tower in the original form of the Transfiguration Church has, however, been vigorously disputed, most notably by Petr Baranovskii, the distinguished specialist in the restoration of medieval Russian churches. Baranovskii visited Solovki in 1922 and 1923, a critical period both before and after the fire, of mysterious origins, that swept through the central ensemble of the monastery in 1923. The photographs and sketches that he and his assistants made after the fire (under extraordinarily difficult conditions) comprise an invaluable record not only of the architecture of the monastery, but also of the catastrophe visited upon it. ${ }^{31}$ Indeed, it can be argued that Baranovskii's persistent negotiations with Soviet authorities (in particular the GPU) led to the conservation of what remained in the ruins.

Baranovskii's conclusion, based on a close examination of the roof masonry (cleared by the fire of later modifications), was unequivocally opposed to the idea of a shatior tower in the original sixteenth-century design. ${ }^{32}$ For Baranovskii the typically Novgorodian begunets pattern (a decorative band consisting of open triangles formed by brick edges joined at a 45-degree angle) on the upper part of the drum indicated the culminating point of the original masonry. The apparent evidence in iconographic sources was dismissed out of hand as an exaggeration typical of such sources, and thus typical of their unreliability. (A. G. Mel'nik has suggested that the appearance of the tower is an attempt by the 


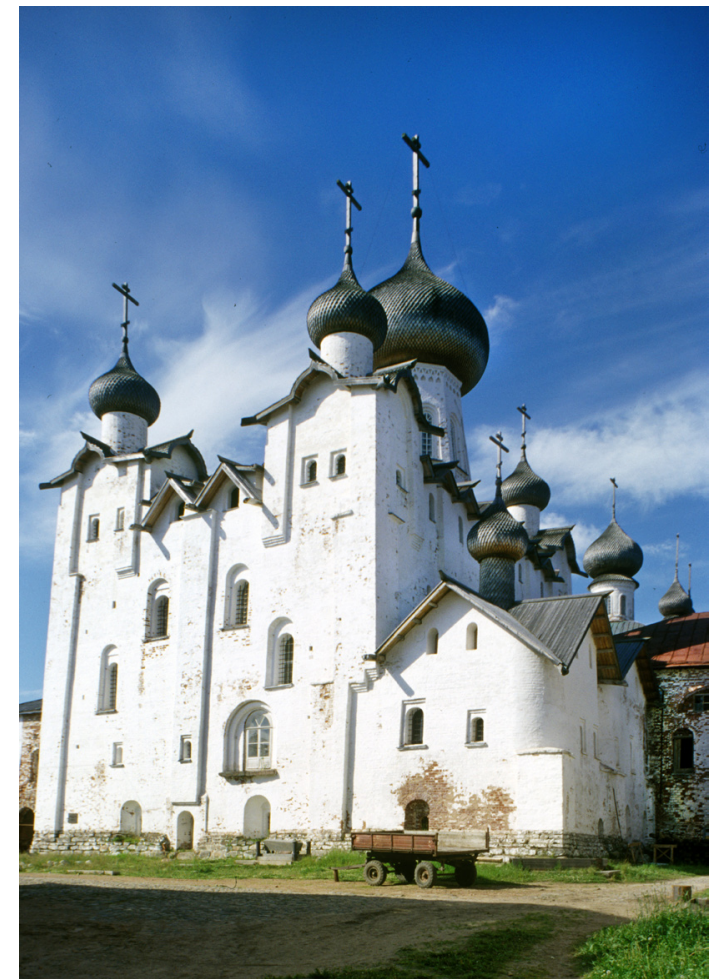

Fig. 19. Cathedral of the Transfiguration. Southeast view. 1998

monastic painters to create an ideal version in emulation of such great shrines as the Cathedral of the Intercession on the Moat. ${ }^{33}$ The recent restoration of the main cupola, supervised by Olga Savitskaia, accepts Baranovskii's opinion on the structure of the drum, but the controversy is likely to continue. ${ }^{34} \mathrm{With}$ the recent cleaning of the interior, one can see at the upper reaches of the tower the surviving fresco of Christ Pantokrator (painted not earlier than the late seventeenth century), preserved against all odds on the vault beneath the cupola (cf. Fig. 15). ${ }^{35}$

Of the many distinctive features of the Transfiguration Church, one of the most unusual is the placement of four additional altars (pridely) beneath cupolas at the corners of the upper structure. These chapels also play a role in the symbolic, dedicatory program of the church: two are dedicated to the twelve apostles and the seventy disciples, indicative of the role of the

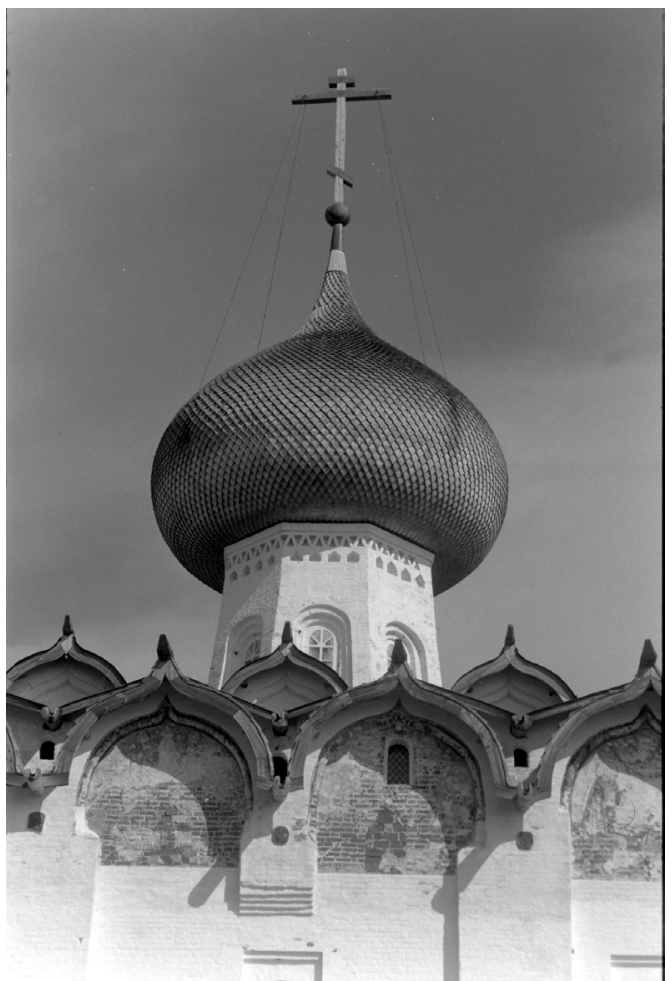

Fig. 20. Cathedral of the Transfiguration. West facade, cornice gables. 1999

monastery as propagator of the faith; and two are dedicated to the Greek saints John Climacus and Theodore Stratilates - heavenly patrons of Ivan the Terrible's sons Ivan and Fedor. Access to these aeries came through narrow stairwells designed within the outer brick walls.

On the exterior the height of the basic structure of each corner chapel is indicated by a short pilaster projecting from the inside corner on the main facade (Fig. 19). Each chapel facade concludes in a single arch that indicates the curve of a barrel vault. The crossing of these vaults creates a solid (blind) groin vault, which in turn supports a drum and cupola. ${ }^{36}$ These four chapels are connected by an arcade whose outer side is blind, with the exception of small window openings. Thus, the outer wall of the arcades serve as a culmination of the upper part of the main facade, and the points of the arcade define the distinctive kokoshnik pattern, in two 


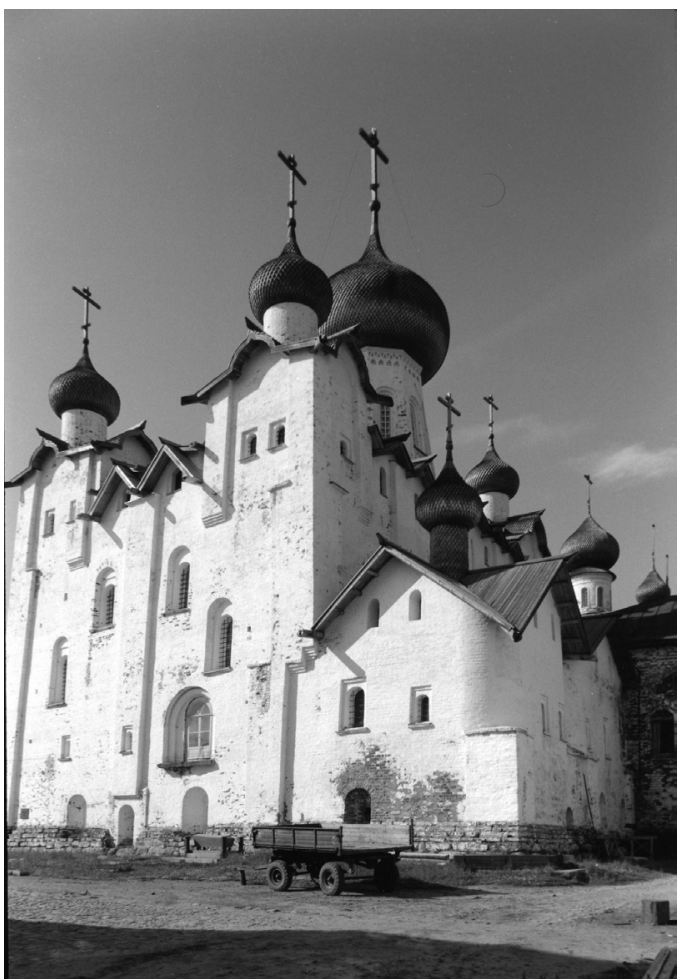

Fig. 21. Cathedral of the Transfiguration. Southeast view. 1998

rows, of the Transfiguration Church roofline. ${ }^{37}$ (Fig. 20) Correspondingly, the ceiling vaults of the basic structure of the church occur at the base of the corner chapels, not at the top of the facades, a device that creates the illusion of a larger structure.

The corner chapels also endow the Transfiguration Church with one of the traditional attributes of medieval Russian architecture: a pentacupolar design. Yet, as the preceding description indicates, this is not a typical grouping of five domes over large churches, with the drum of each dome admitting light to the interior. (The Annunciation Cathedral at Sol'vychegodsk is closer to that tradition.) Here, the innovations in sixteenth-century construction techniques again provide new approaches to traditional designs. Not only do the structures beneath the four subsidiary cupolas not admit light to the main structure, they are self-contained structures,

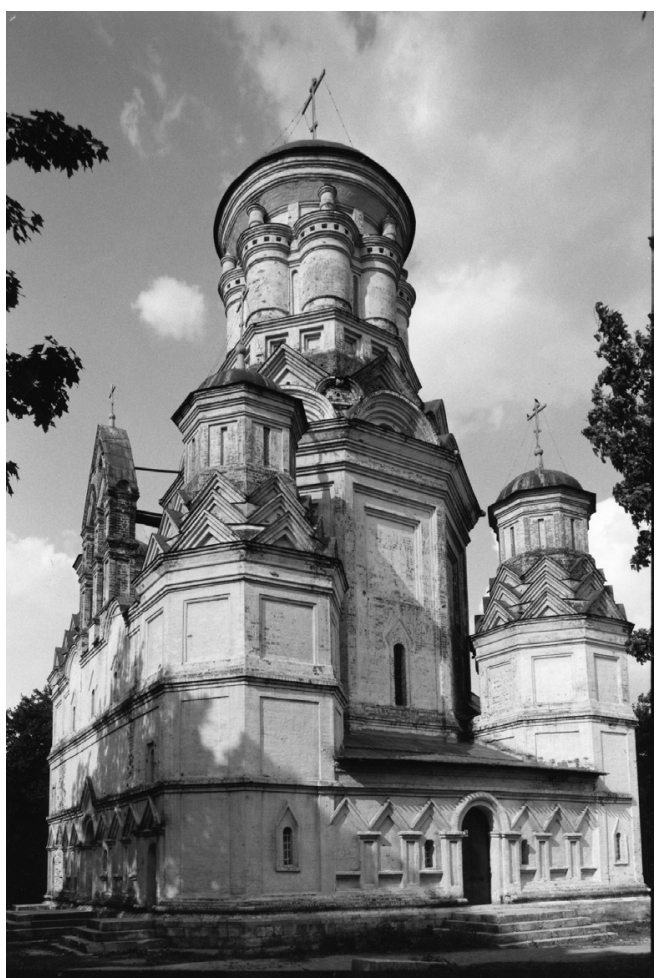

Fig. 22. Moscow. Church of the Decapitation of John the Baptist, south view. 1994

situated at sufficient distance from the main dome to create their own distinct visual existence. Indeed, in view of the secondary role of Russian monasteries as fortifications, one might see these chapels in another role, as watch towers (Fig. 21), a precursor of the Renaissance oreillon that Peter the Great would import for his major fortress.

Yet, such speculation is secondary to the corner chapels' obvious and primary role in defining the sacred meaning of the Transfiguration Church. Their dedications have been mentioned above, and together with the altars within the main structure they form a devotional network of seven altars (sacred number) remarkable for its comprehensiveness. Furthermore, their placement as separate structures around a central cupola (or tower) suggests comparison with some of the most distinctive churches of sixteenth-century Muscovy, in particular the Church of the Decapitation of John the Baptist at 


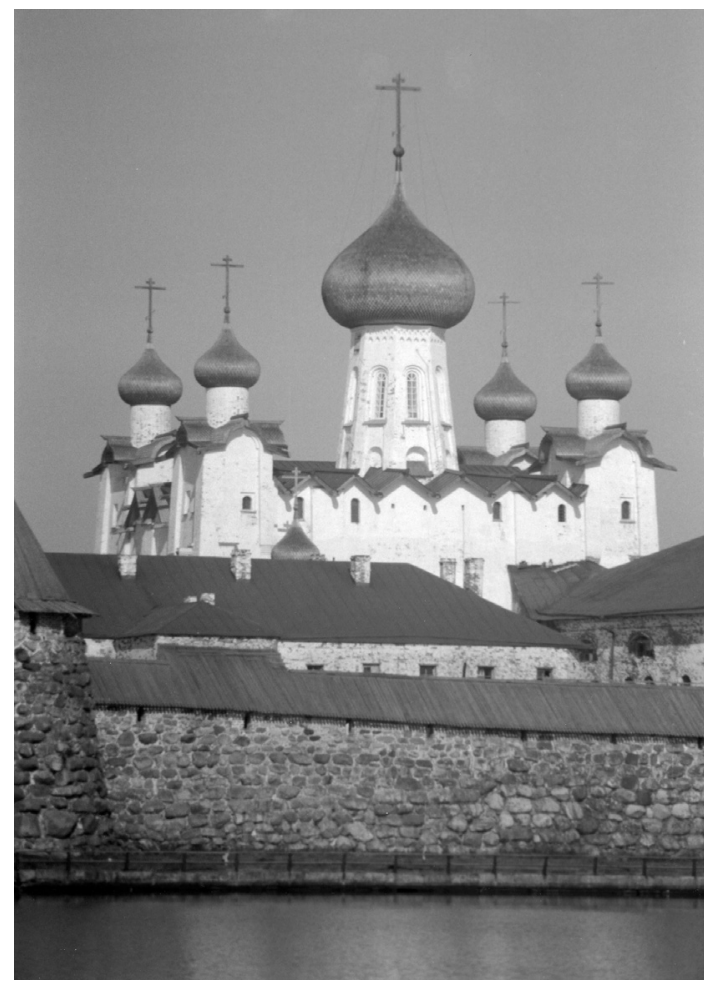

Fig. 23. Cathedral of the Transfiguration. West view from harbor. 1998

Diakovo (Fig. 22) and Moscow's Cathedral of the Intercession on the Moat. ${ }^{38}$ Both of the Moscow monuments consist of free-standing chapels, or pridely (four in the case of the Diakovo church, eight in the Intercession Cathedral), grouped around a central tower.

There are, however, obvious structural differences: the chapels (actually small churches) of the Moscow monuments rise together with the main structure from a common base. The base of the Intercession Cathedral is elevated over a podklet, or ground floor, but the organizing principle is the same: detached secondary structures symmetrically grouped around a primary tower. The Transfiguration Church also rests on a podklet, but its chapels are placed at the upper corners of the main structure, not on its base (Fig. 23). One could note a precedent in the Diakovo church, which has two elevated chapels behind the bell gable over the west front; but the overall design is significantly different. In its unique way, therefore, the Solovetskii Transfiguration Church combines the traditional five-domed form of the Russian Orthodox church with the image of heavenly fortress, whose parts are symbolically placed around the central structure, dedicated to the Transfiguration.

Even as work on the Transfiguration Church moved toward its conclusion in preparation for the consecration of the altars (August 6, 1566), Filipp was compelled to abandon the enterprise that had so engaged him. In the summer of 1566 he was summoned to Moscow by Ivan the Terrible, who supported Filipp's appointment as metropolitan of the Russian Church but expected the prelate to acquiesce in his reign of terror. When Filipp not only withheld consent but publicly protested the rampage, Ivan exiled him in 1568 to the Otroch Monastery in Tver, where on the tsar's order he 


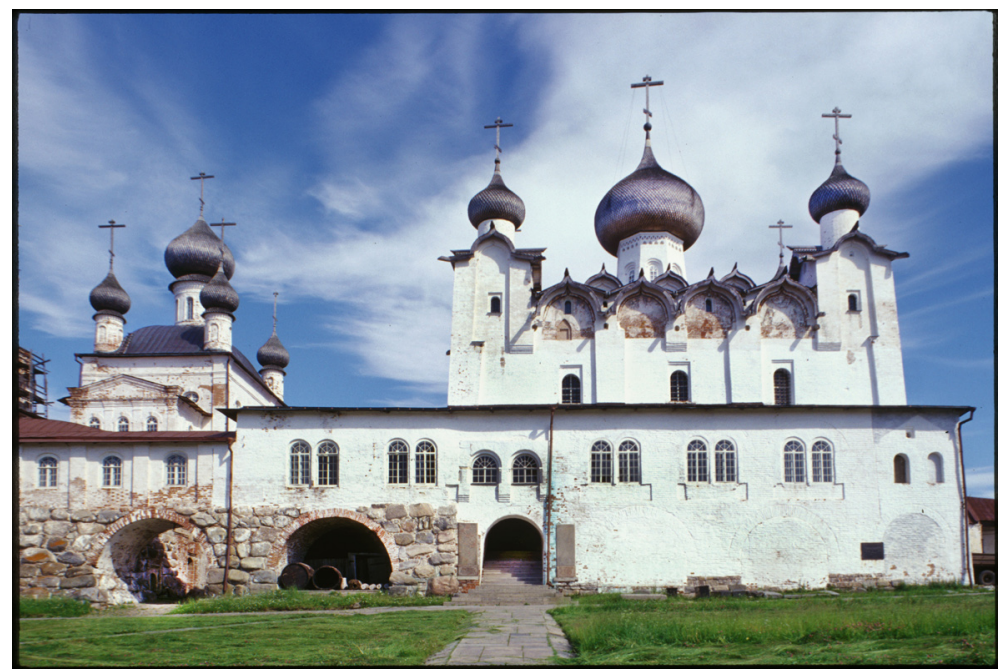

Fig. 24. Cathedral of the Transfiguration and gallery. Left: Church of St. Nicholas. West view. 1998

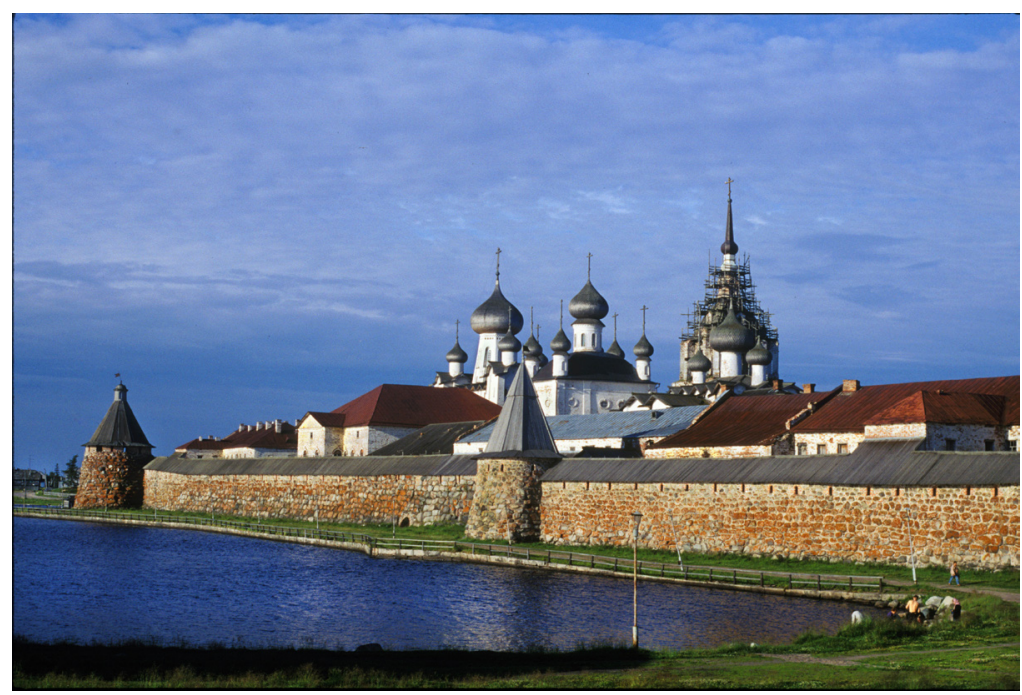

Fig. 25. Solovetskii Transfiguration Monastery. East wall, northeast view. 1998

was killed by Maliuta Skuratov on December 23, 1569 (O.S.) ${ }^{39}$ Filipp was canonized in 1647, and five years later his relics were transferred to Moscow's Dormition Cathedral.

Despite the death of metropolitan Filipp and the disorder of Ivan's reign, construction work at the Solovetskii Monastery continued. A third masonry church, dedicated to Saint Nicholas, was begun in 1577 and completed in 1584 on a site between the refectory Church of the Dormition and the Transfiguration Church.
Modest in size and elevated on a podklet (called a pogreb in eighteenth-century documents), the church apparently was two-piered, with one cupola and a bell gable over the west facade. ${ }^{40}$ Typical for northern churches, the roof was of wooden with wooden shingles for the cupola. At the beginning of the nineteenth century the monastery administration decided to raze the structure because of structural defects (cracks in the facade). In 1830-1834 a larger Church of Saint Nicholas, with five cupolas, was built on the same 
site and possibly incorporated remnants of the original walls (Fig. 24). ${ }^{41}$

Much greater in scale and significance was the building of the massive granite walls of Solovetskii Monastery. Although little known outside Russia, the Solovetskii Monastery walls are one of the most remarkable achievements of fortification engineering in Europe (Fig. 25). The impulse for their construction came from Ivan the Terrible's prolonged Livonian War, which lasted from 1558 to 1583 . As part of that conflict, a combined Dutch and Swedish flotilla appeared off the Solovetskii Archipelago in 1571. Although no hostile action ensued from this probing mission, it raised questions about the vulnerability of the monastery and, more generally, of Muscovy's northern approaches via the White Sea.

In 1578 Ivan the Terrible supported the building of a log wall around the monastery and sent a detachment of strel'tsy and cannoneers under the command of the voevoda Mikhail Ozerov in order to counter Swedish moves in the White Sea. ${ }^{42}$ In 1579, however, Ozerov died in a vain attempt to dislodge the Swedes from their occupation that year of monastery lands near Kem', the nearest mainland settlement to Solovki. This defeat served only to increase the resources allocated to the monastery. For with the loss of Narva in 1581, the strategic importance of the White Sea increased not only in military terms but also as Muscovy's sole remaining sea outlet to European trade. By the end of the sixteenth century the entire White Sea area was linked by rivers, lakes, and the sea into one of the most powerful trading networks in medieval Russia. Through this vast territory moved furs, forest products, fish, and that most essential of commodities, salt.

In these circumstances the Solovetskii Monastery became the logical bulwark against a possible Swedish campaign, and in 1582 work began on replacing the log stockade with walls from the most durable available material: granite fieldstone, including large boulders. Even after the conclusion of the Livonian War, in 1583, and the death of Ivan the Terrible, in 1584, work on the walls continued with the support of an ukaz by tsar Fedor. ${ }^{43}$ When completed, the walls formed an elongated pentagon approximately 850 meters in basic length (not including tower circumferences), an average of nine to ten meters in height, and some seven meters thick at their base.

During the period of most intensive construction work, between 1582 and 1594, monks and hired labor manhandled thousands of granite boulders into place as the great walls and round towers of the monastery arose from the marshy ground. During the first two years of construction, work was apparently guided by a master builder from Vologda, Ivan Mikhailov. However, the monastery had gained much experience in the use of granite boulders for large structures, including churches, during the $1550 \mathrm{~s}$ and 1560s. Written sources indicate that overall supervision of the project was assigned to the monk (starets) Trifon, born Terentii Kologrivov and member of a prosperous family of salt merchants from the White Sea village of Nenoksa (near the mouth of the Dvina). ${ }^{44}$

Like many Russian settlements in the White Sea area (Pomor'e), Nenoksa was drawn into the orbit of the Solovetskii Monastery during the sixteenth century. From towns such as Kem' and Sumskii Posad along the "Summer Shore" (the southwestern shore of the sea in what is now Karelia), to villages along the "Winter Shore" and the Terskii Shore of the Kola Peninsula, the monastery provided priests and, from the seventeenth century, trained local icon painters. 45 This influence involved not only spiritual matters but also economic interests, as the monastery had been granted extensive land holdings in many of these areas. Furthermore, the monastery's 
location near the mouth of the Onega River gave it access to the interior of the Russian north.and particularly to the ancient salt trading center of Kargopol, located on Lake Lacha at the origins of the Onega River.

Thus the enormous enterprise of building the walls was supported not only by sporadic grants from the Muscovite court and the monastery's immediate resources on the archipelago, but also by a network of settlements, some of which had specific (and often onerous) obligations to the monastery.46 It is also known that during the summer months as many as 200 hired kazaki participated in the building of the walls. 47 At the same time these mainland holdings were subject to Swedish raids, particularly in the early 1590 s, and their defense posed an additional burden to the monastery's resources. 48

The most distinctive elements of the walls are the six massive round corner towers. They include: the Saint Nicholas Tower and entrance gate, at the northeast corner (Fig. 26); the Archangel Tower at the southeast corner (Fig. 27); the White Tower at the west point (Fig. 28); the Spinning (priadil'naia) Tower on the southwest (Fig. 29); and the Watch (korozhnaia) Tower at the northwest corner (Fig. 30). There are also four square towers of smaller dimensions. The towers, like the walls themselves, were topped with brick for gun ports (Fig. 31), and the entire system was

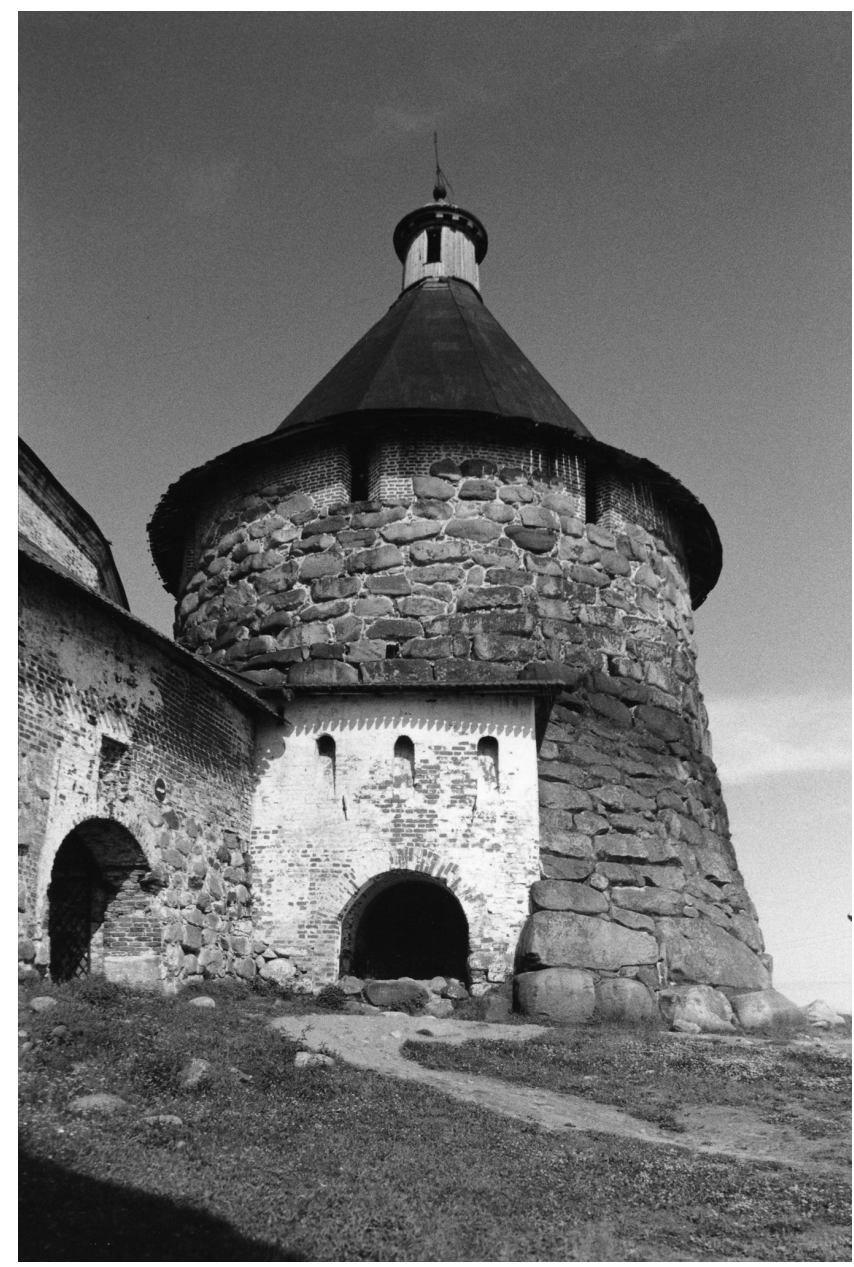

Fig. 26. St. Nicholas Tower and entrance gate. South view. 1998 


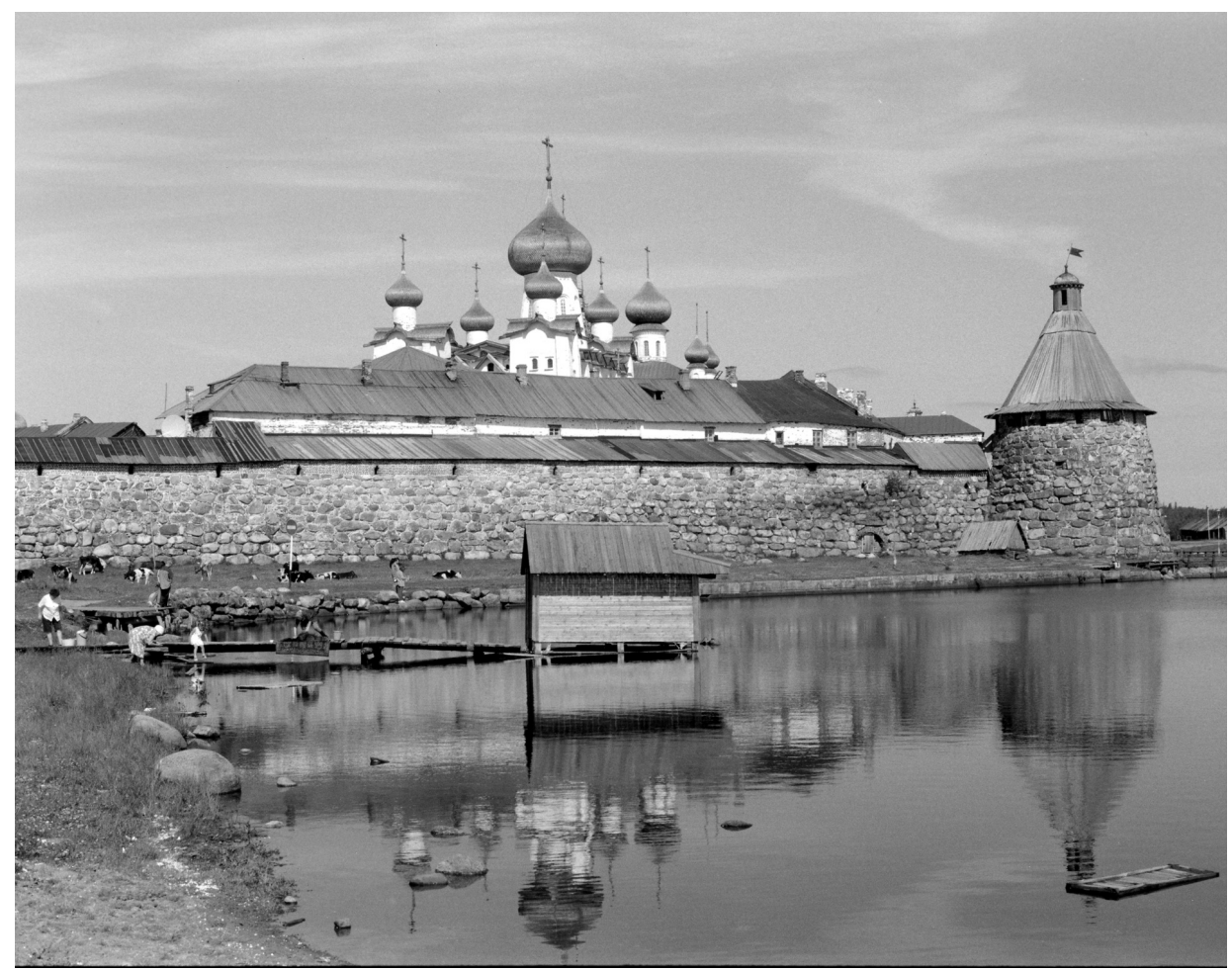

Fig. 27. Archangel Tower and south wall. South view. 1998

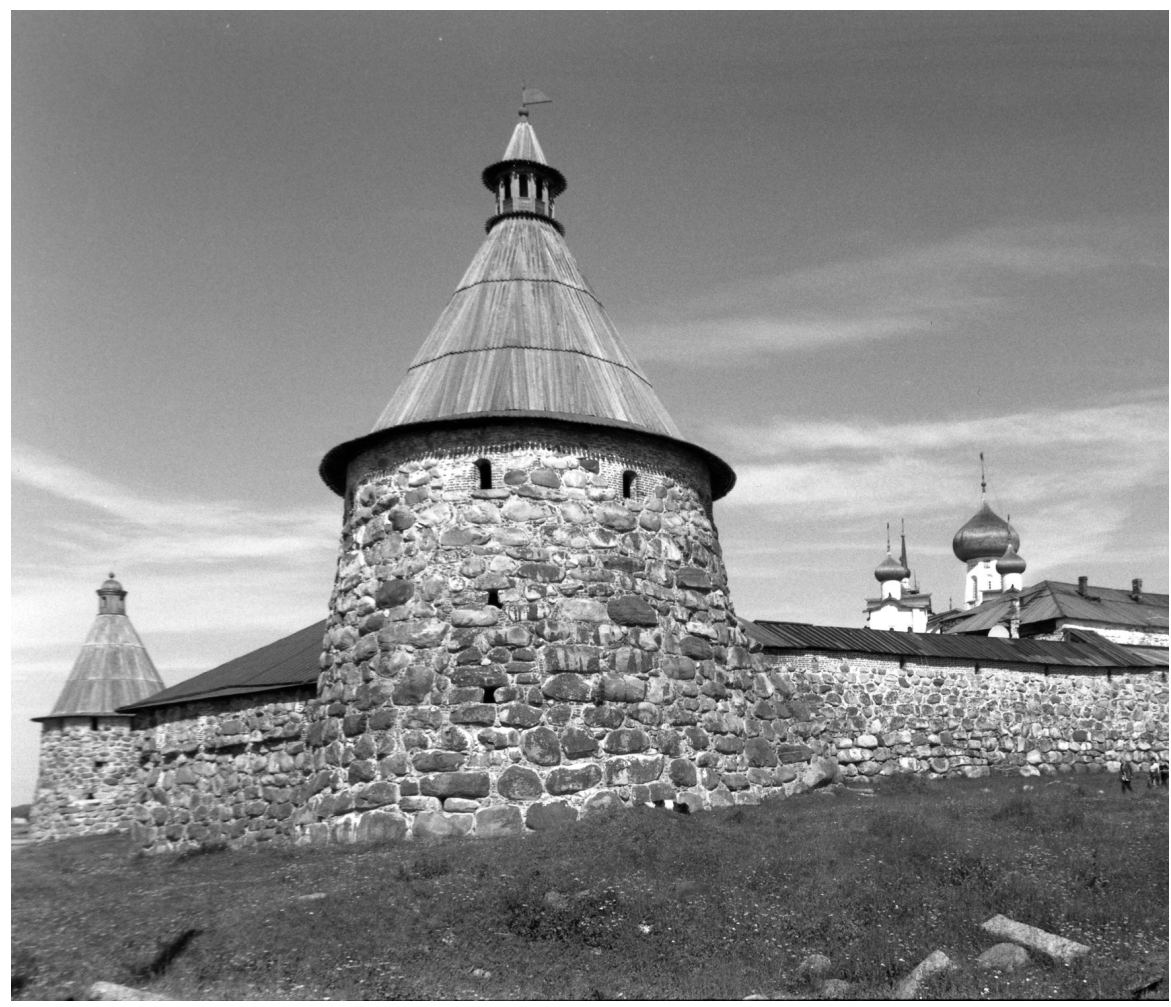

Fig. 28. White Tower and south wall. East view. 1998 


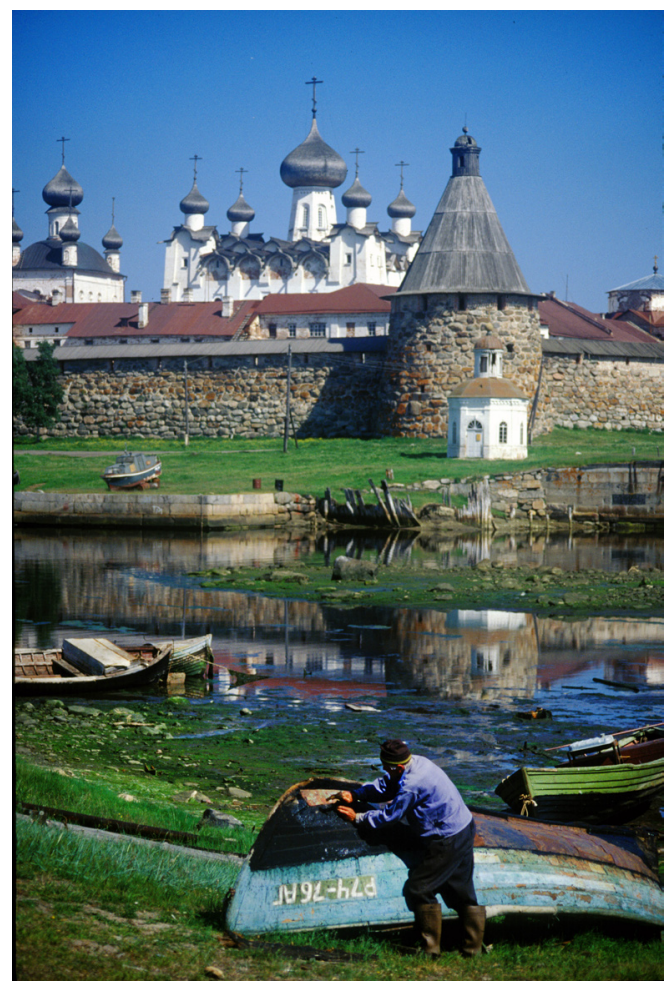

Fig. 29. Spinning (priadil'naia) Tower and west wall. Southwest view. 1999

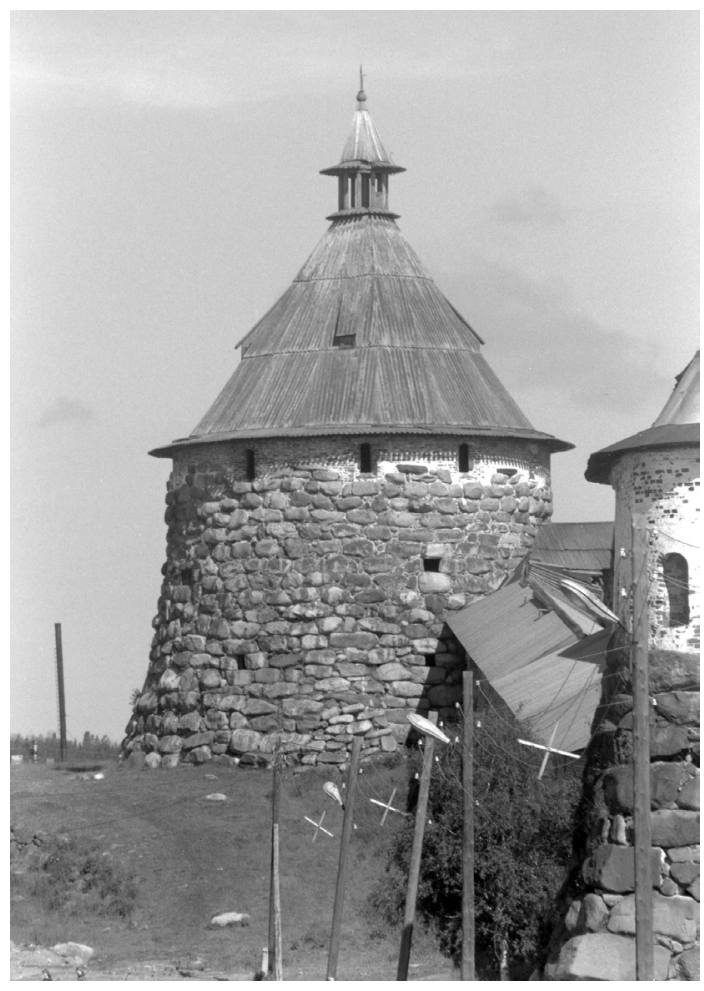

Fig. 30. Watch (korozhnaia) Tower. South view. 1999

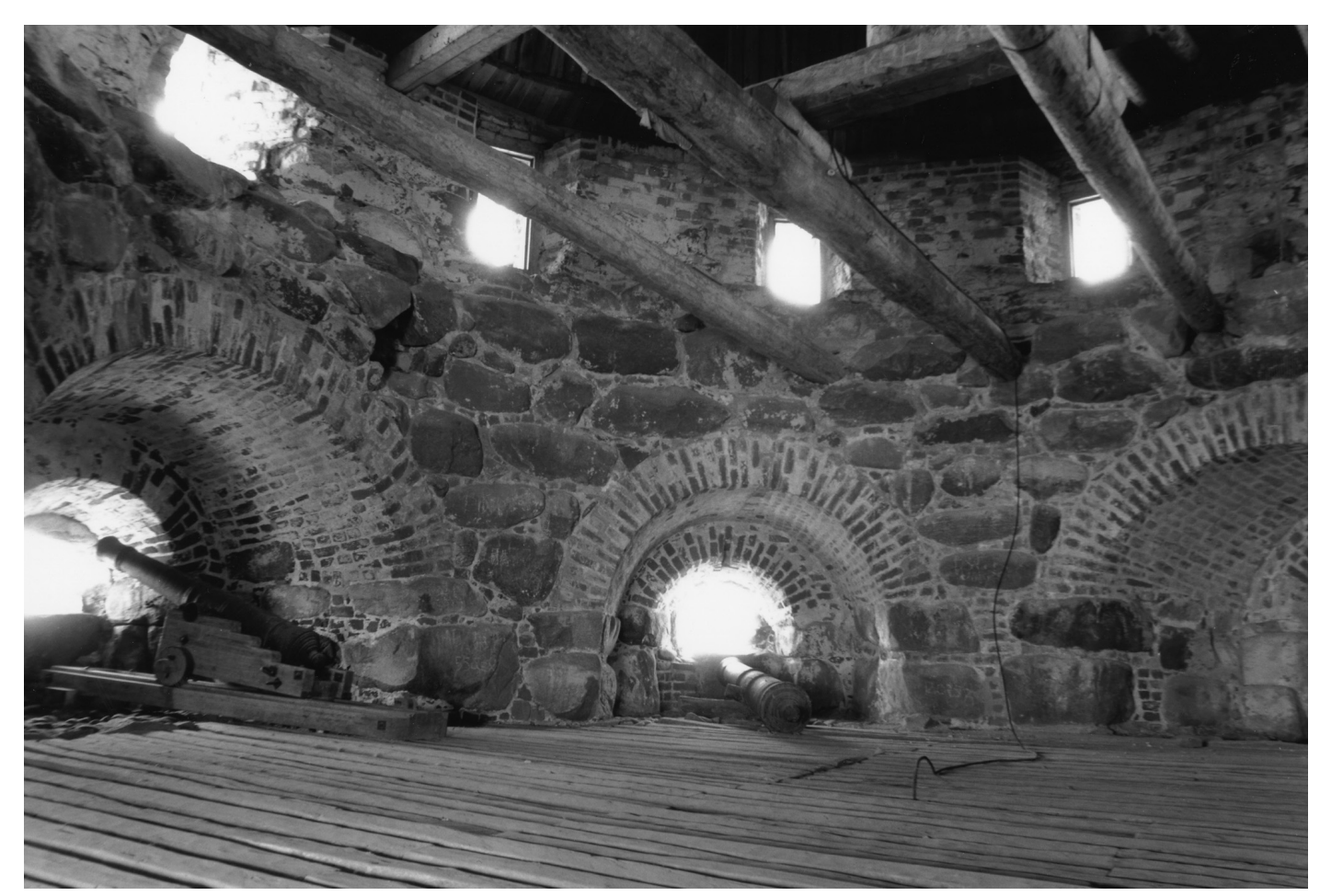

Fig. 31. Spinning (priadil'naia) Tower. Interior, upper level with gun ports. 1999 
covered with a wooden roof, including tent forms over the towers themselves. The towers were among the last major elements of the wall system to be completed. With the signing of a peace treaty (typically short-lived) between Russian and Sweden in 1595, the urgency of completing the walls lessened. Nonetheless, records indicate that construction continued until 1596, resumed again in the early seventeenth century, and reached its conclusion only in $1621{ }^{49}$

The final major structure in the sixteenth century at Solovetskii Monastery is the gate Church of the Annunciation (Fig. 32), built in 1596-1601 over the main west gate and still extant, if much modified in the nineteenth century. (It currently serves the parish needs of the local community.) The Annunciation
Church is yet another monastery structure attributed to the monk Trifon, although its present appearance conveys only an approximate idea of the original form.50 For example, the original roofline resembled that of the Dormition Church, with decorative gables beneath the one cupola. The interior also has been frequently modified and enlarged. Yet the simple white-walled form of the church not only an effective contrast to the rustic texture of the walls, but it also serves as a counterpoint to the main monastic structure, the Church of the Transfiguration, whose west entrance stand opposite the gate church. Thus, with the completion of the gate church the monastery had three significant visual dominants, each dedicated to one of the most sacred mysteries of

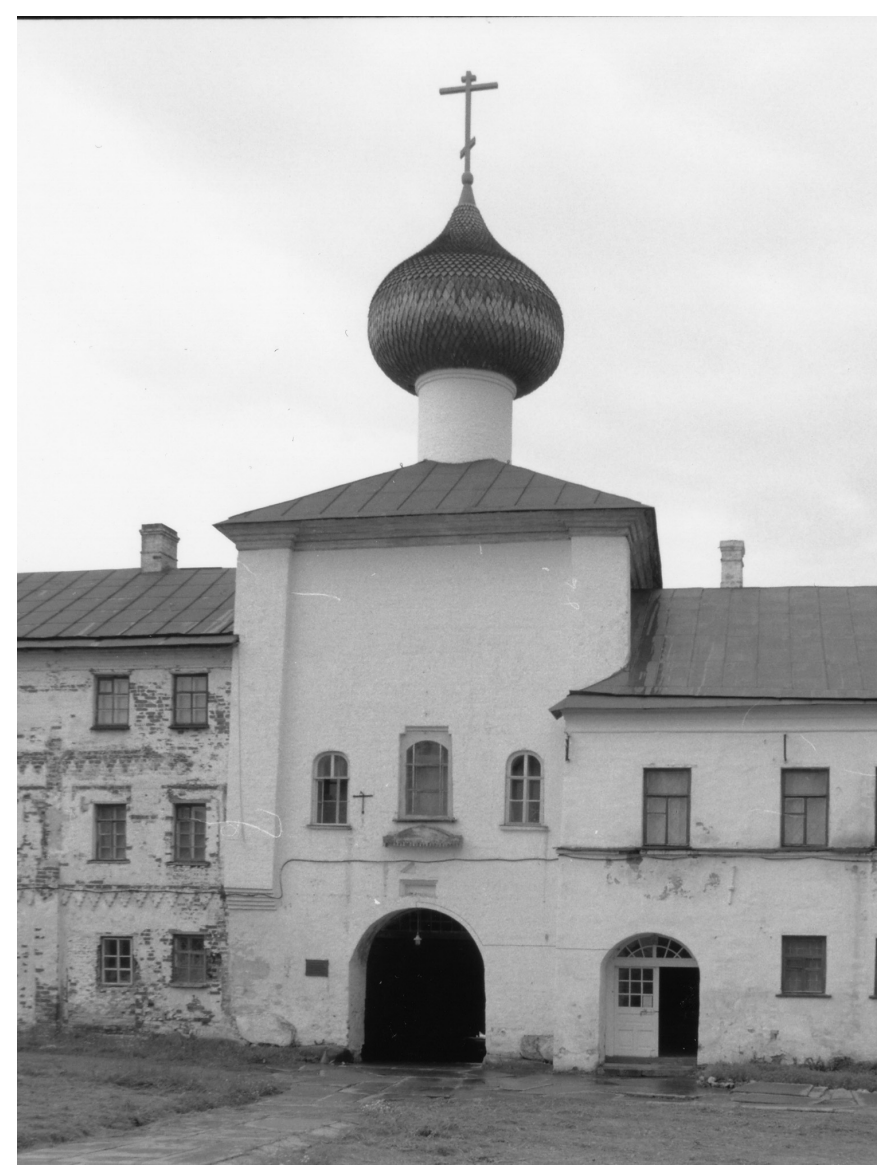

Fig. 32. Gate Church of the Annunciation. East view. 1998 
Orthodoxy: the Dormition, the Transfiguration, and the Annunciation.

This survey of sixteenth-century architecture at Solovetskii Monastery concludes with brief note of a structure that dates from the beginning of the seventeenth century, but is inextricably linked to the monastery's sixteenthcentury churches. In 1602 Trifon Kologrivov supervised the construction of an enclosed stone gallery (Fig. 33) connecting the central churches, from the Dormition to the Transfiguration. When completed, the gallery provided welcome protection against winter storms. Although some structures attached to that gallery are no longer extant, the basic form survives and gives further evidence of the builders' remarkable sensitivity to materials and design. The massive base of granite boulders yields to the precision of brickwork that not only physically connects the structures but also provides a unifying visual base for the ensemble. $^{51}$

The Solovetskii Transfiguration Monastery was largely spared the depredations of the Time of Troubles. But before the end of the seventeenth century the monastery was fated to endure one of its most tragic episodes. In the $1660 \mathrm{~s}$ the Russian Orthodox community split over the issue of liturgical reforms promulgated by Patriarch Nikon, and the Solovetskii monastery became a leading point of resistance. Only after a sevenyear siege by the tsar's troops (1668-1676) did the monastery fall when one of the monks betrayed the fortress through a secret entrance. The subsequent execution or exile of the rebellious monks made the monastery a symbol of Old Believer martyrdom, but it was gradually repaired and resettled.

From the seventeenth century through the nineteenth centuries the monastery constantly evolved, as old structures were replaced by new, such as the present bell tower (1776-1777), which provides another vertical accent in the central ensemble (Fig. 34). The construction of large brick buildings for various crafts and enterprises remind that the monastery had created a selfsustaining community encompassing all the

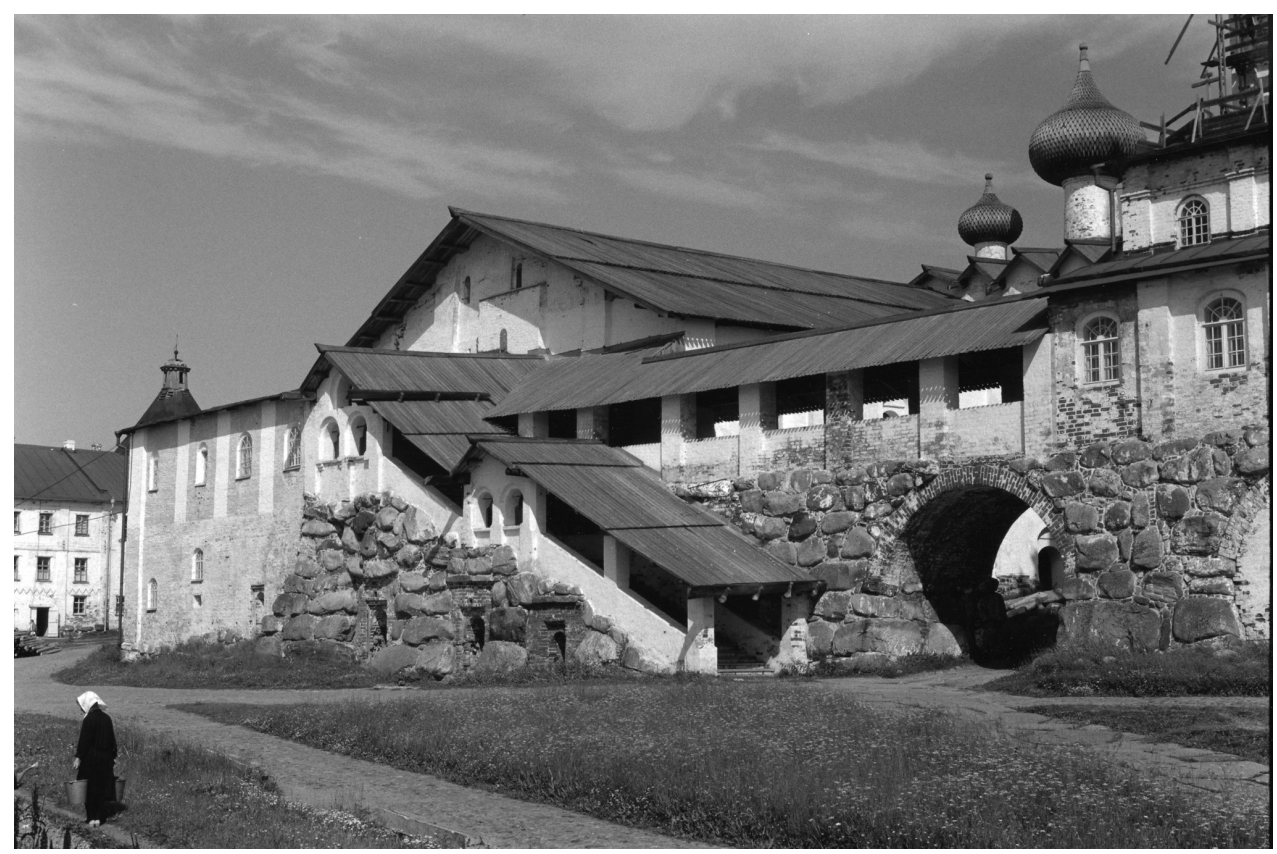

Fig. 33. Gallery, view toward Refectory Church of the Dormition. Southwest view. 1998 


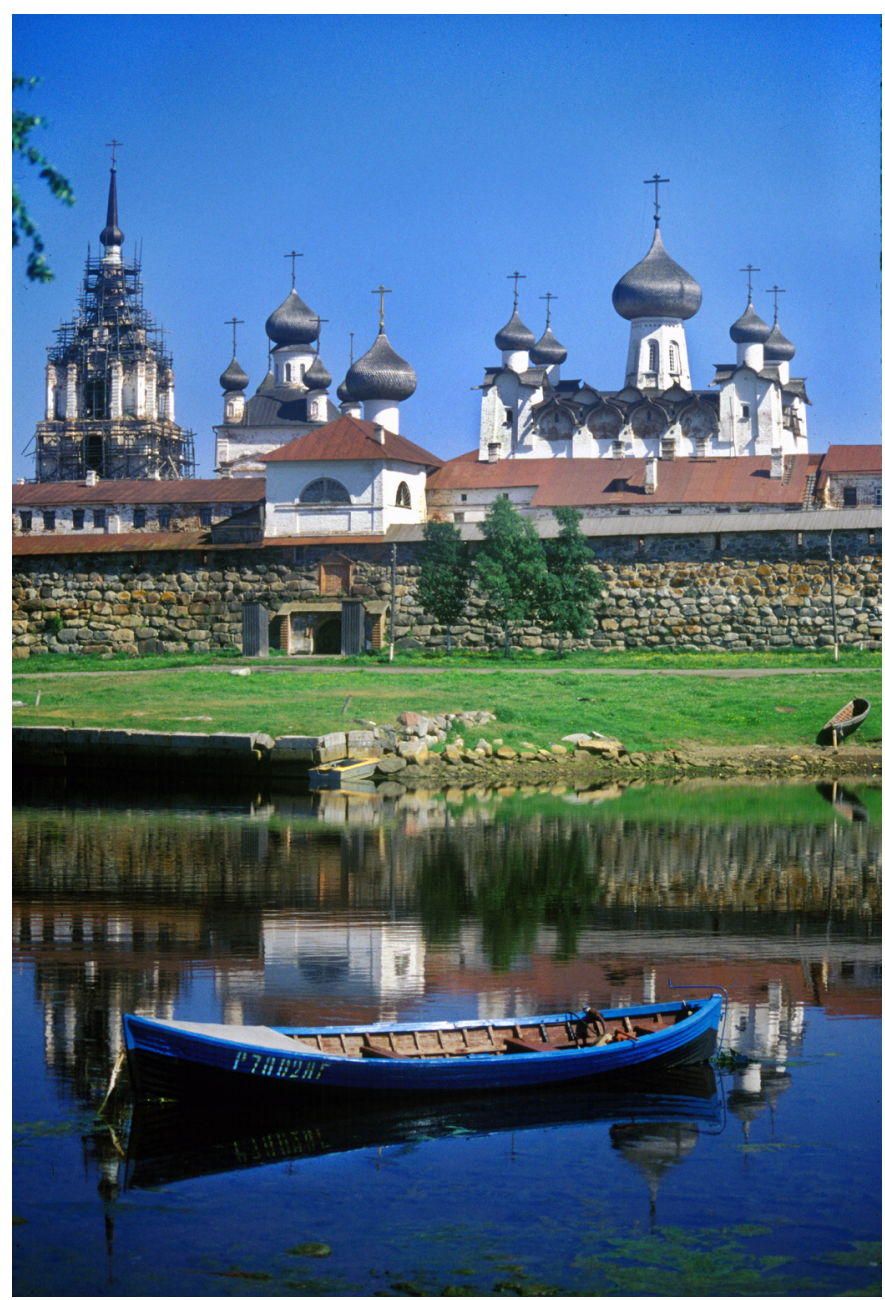

Fig. 34. Solovetskii Transfiguration Monastery. West view across harbor. From left: Bell tower, Church of St. Nicholas, Gate Church of the Annunciation, Transfiguration Cathedral

islands of the Solovetskii archipelago, which provided additional resources as well as places for spiritual retreat. Great Zaiatskii Island, for example, contains not only prehistoric stone labyrinths, but also the log Church of St. Andrew, built on order of Peter the Great in 1702. During the nineteenth century the monastery became a major pilgrimage site, with its own steamship and hotel.

After the end of the Russian civil war in 1921, the Bolsheviks expropriated the monastery, which briefly - and unsuccessfully - existed as a commune. Two years later, a fire of unknown origins spread throughout the central stone churches and reduced their interiors to charred rubble. Soon thereafter, the archipelago received its first wave of prisoners, for it was here, in 1923, that the Soviet regime established the first concentration camp specifically designated for political suppression. Superseded by larger camps, the Solovetskii camp closed in 1939, and the territory became a military base and school for naval cadets.

Modest attempts to restore the Transfiguration Monastery began in the 1960s and gathered strength in subsequent decades after the establishment of the Solovetskii State Historical Museum Territory. In the 1990s, students and 


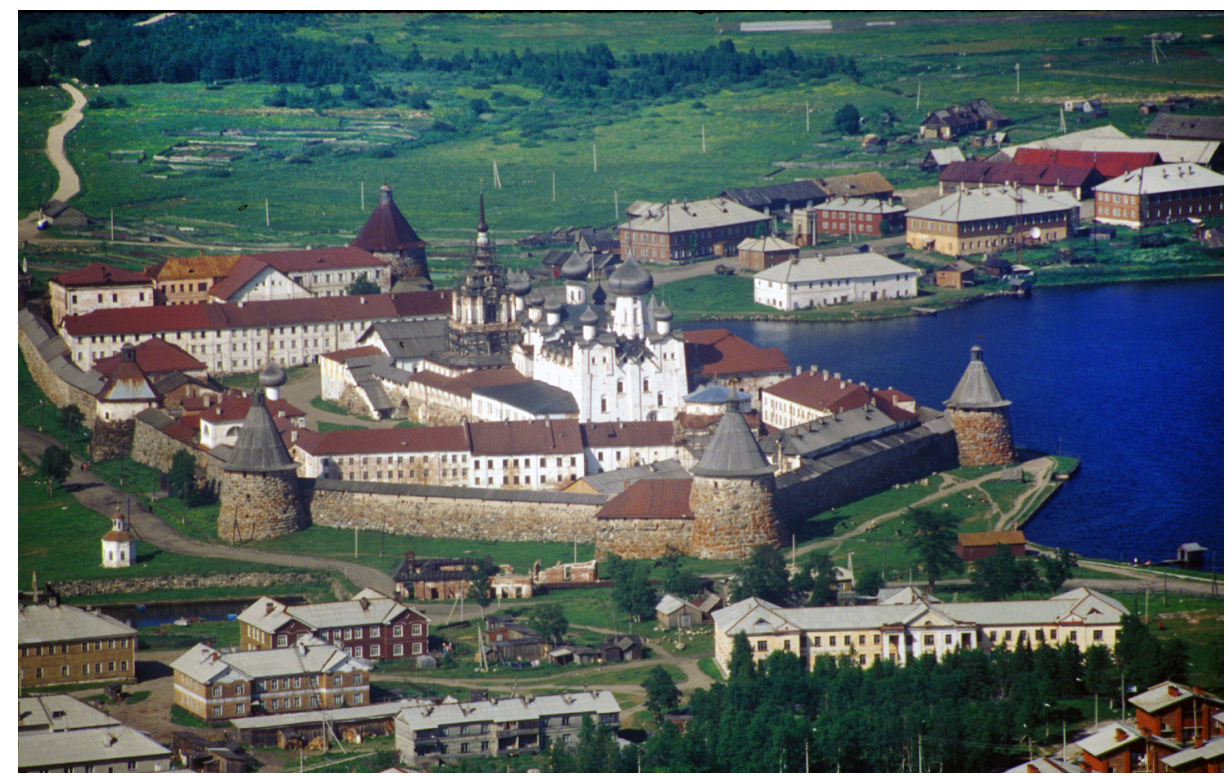

Fig. 35. Solovetskii Transfiguration Monastery. Aerial view. 1999

other volunteers came north in the summer to help the few monks currently living in the monastery with the task of renovation. Following the reconsecration of the monastery by Patriarch
Aleksii in August 1992, work accelerated, culminating in 2001 with the opening of the stone gallery connecting the central monastic churches. The restoration continues (Fig. 35).

1 The archipelago consists of several islands, including Large Solovetskii $\left(246 \mathrm{~km}^{2}\right)$, Anzer $\left(47 \mathrm{~km}^{2}\right)$, Large Muksalma (17 $\left.\mathrm{km}^{2}\right)$, Small Muksalma $\left(.57 \mathrm{~km}^{2}\right)$, Large Zaiatskii $\left(1.25 \mathrm{~km}^{2}\right)$, and Small Zaiatskii $\left(1.02 \mathrm{~km}^{2}\right)$. For a survey of the ecology of Large Muksalma Island (less touched by development than Large Solovetskii), see G. I. Kolosova, "Prirodnye kompleksy," in P. V. Boiarskii, ed., Solovetskie Ostrova: Bol'shaia Muksalma (Moscow, 1996), 137-84.

2 O. D. Savitskaia, "Arkhitektura Solovetskogo monastyria," in D. S. Likhachev, ed., Arkhitekturno-khudozhestvennye pamiatniki Solovetskikh ostrovov (Moscow, 1980), 74.

3 On the labyrinths and other neolithic remains, particularly on Big Zaiatskii Island, see Vladimir V. Skopin, Na Solovetskikh ostrovakh (Moscow: Iskusstvo, 1990), 151-54. On early Slavic archeological finds in the Solovetskii archipelago, see Nikolai A. Makarov, Kolonizatsiia severnykh okrain Drevnei Rusi v XI-XIII vekov (Moscow, 1997), 13, 47, 87.

4 The traditional way to approach Large Solovetskii Island is by boat from towns such as Kem' on the Karelian shore, located some 40 kilometers to the west. The spiritual significance of the passage by sea is discussed in B. A. Uspenskii, "Dualisticheskii kharakter russkoi srednevekovoi kul'tury (na material 'Khozhdeniia za tri moria' Afanasiia Velikogo)," Izbrannye trudy v dvukh tomakh, vol. 1 (Moscow,1994), 255. See also N. M. Terebikhin, Sakral'naia geografiia Russkogo Severa (Arkhangelsk, 1993), 43.

5 It should be noted that the Valaam monastery was dedicated to the Transfiguration of the Savior. For sources on the life of Saints Savvatii and Zosima, see Sof'ia V. Mineeva, ed., Zhitie i chudesa prepodobnykh Zosimy i Savvatiia solovetskikh chudotvortsev; (Kurgan, 1995); Sof'ia V. Mineeva, Rukopisnaia traditsiia Zhitiia prep. Zosimy i Savvatiia Solovetskikh (XVI-XVIII vv.) (Moscow, 2001); and Rufina P. Dmitrieva, "Zhitie Zosimy i Savvatiia solovetskikh v redaktsii SpiridonaSavvy," in Dmitrii S. Likhachev and Rufina P. Dmitrieva, eds., Knizhnyi tsentry Drevnei Rusi: XI-XVI vv.: Raznye aspekty issledovaniia (Saint Petersburg, 1991). See also Ivan Iakhontov, Zhitiia sviatykh severorusskikh podvizhnikov pomorskogo kraia, kak istoricheskii istochnik (Kazan, 1882). For other secondary work see the dissertation by Jennifer Spock, The Solovki Monastery 1460-1645: Piety and Patronage in the Early Modern Russian North (Yale University, 1999). On the Kirillo-Belozerskii Monastery and its architecture, see William C. Brumfield, "Photographic Documentation of Architectural Monuments in the Russian North: Vologda Province," Visual Resources 14(1998)1:71-78.

6 Dmitrii S. Likhachev, "Solovki v istorii russkoi kul'tury," in D. S. Likhachev, ed., Arkhitekturno-khudozhestvennye pamiatniki Solovetskikh ostrovov (Moscow, 1980), 12-13. A second edition of the Letopisets Solovetskii was published in Moscow in 1821.

$7 \quad$ Vladimir V. Skopin and Liudmila A. Shchennikova, Arkhitekturno-khudozhestvennyi ansambl Solovetskogo monastyria (Moscow, 1982), 15.

8 Leonid I. Denisov, Pravoslavnye monastyri Rossiiskoi imperii (Moscow: A. D. Stupin, 1908), 11.

$9 \quad$ M. V. Kukushkina, “Opis' Solovetskogo monastyria 1549 g.", Arkheograficheskii ezhegodnik za 1971 god (Moscow, 1972), 341-48. 
10 On the significance of the Moscow sobor of 1547 (and 1549) for Muscovite architecture, see Andrei Batalov, Moskovskoe kamennoe zodchestvo kontsa XVI veka (Moscow, 1996), 20. See also Likhachev, "Solovki," 19. More generally on the Moscow Church Council of 1547, see Paul Bushkovitch, Religion and Society in Russia: the sixteenth and seventeenth centuries_(New York, 1992).

11 Skazanie o Filippove stroenii izhe v Solovetskom monastyri, GNB, Sobranie A. I. Popova, F. 236, d. 37, 1. 238. Quoted in Savitskaia, "Arkhitektura Solovetskogo monastyria," 51. A detailed discussion of the work of Ignatii Salka is presented in A. N. Miloradovich, "Novgorodskii master Ignatii Salka," in A. Ia. Martynov, ed., Solovetskii Sbornik. Materialy $i$ issledovaniia, vypusk 1 (Solovki, 1994), 67-87.

12 On the influence of Moscow, see Batalov, Moskovskoe kamennoe zodchestvo, 127; and William Craft Brumfield, A History of Russian Architecture (New York, 1993), 73. On the predominance of Novgorodian features, see D. A. Petrov, "SpasoPreobrazhenskii sobor Solovetskogo monastyria v ego otnoshenii k novgorodskoi arkhitekture pervoi poloviny XVI v.", in L. D. Popova, ed., Pamiatniki arkhitektury russkogo severa (Arkhangel'sk, 1998), 193.

13 See Savitskaia, "Arkhitektura Solovetskogo monastyria," 58. Skopin places the second dedication as a gesture of loyalty on the enthronement of False Dmitrii in 1605. See Na Solovetskikh ostrovakh, 42.

14 See Brumfield, History, 74-75. The sixteenth-century form of the Annunciation Church and its adjoining Church of Archangel Michael is analyzed in L. E. Krasnorech'ev and T. V. Gladenko, "Arkhitektura XVI v.", in M. N. Tikhomirov, ed., Novgorod. K 1100-letiiu goroda (Moscow, 1964), 250-51.

15 See, for example, the Church of Saints Peter and Paul in Slavno (1367) in Brumfield, History, color plate 17.

16 On the Krestovaia palata and German construction technique, see E. A. Gordienko, Vladychnaia palata novgorodskogo kremlia (Leningrad: Lenizdat, 1991), 34-36. Gordienko notes that there are no known documents with the designation "krestovaia palata" before the seventeenth century, but this does not preclude the likelihood of German influence on the cross-vaulting system.

${ }_{17}$ See "Granovitaia palata so Sviatymi seniami," in A. I. Komech and V. I. Pluzhnikov, eds., Pamiatniki arkhitektury Moskvy: Kreml'. Kitai-gorod. Tsentral'nye ploshchadi (Moscow, 1983), 330-31.

18 On the dimensions, see Skopin and Shchennikova, Arkhitekturno-khudozhestvennyi ansambl, 17; and Savitskaia, "Arkhitektura Solovetskogo monastyria," 53.

19 See Skopin, Na Solovetskikh ostrovakh, 41; and Savitskaia, "Arkhitektura Solovetskogo monastyria," 59. For a smaller, but analogous example of heating system at Ferapontov Monastery, see Brumfield, "Photographic Documentation," 81.

20 Savitskaia, "Arkhitektura Solovetskogo monastyria," 74. For a detailed report on the restoration of the Transfiguration Church, see O. D. Savitskaia, "Issledovaniia i restavratsiia Spaso-Preobrazehskogo sobora Solovetskogo monastyria," in Martynov, ed., Solovetskii Sbornik, 6-37.

${ }_{21}$ See Batalov, Moskovskoe kamennoe zodchestvo, 113, 120. On the traditional, Byzantine-inspired cross-inscribed plan, see Brumfield, History, 11-15.

22 On the link between the heightening of the multi-tiered iconostasis and the development of the two-piered church, see Petrov, "Spaso-Preobrazhenskii sobor," 197-98. See also M. A. Il'in, Russkoe shatrovoe zodchestvo (Moscow, 1980), 103.

23 Further comments on the structure of the Annunciation Cathedral are contained in William C. Brumfield, "Sixteenth and Seventeenth-Century Church Architecture in Vologda Province," Biuletyn Historii Sztuki, 60(1998)1-2:34-35.

24 For other examples of low rectangular apsidal structures in Novgorod churches, see Petrov, "Spaso-Preobrazhenskii sobor," 202. See also V. A. Burov, "K voprosu o rekonstruktsii nizhnikh pridelov Preobrazhenskogo sobora Solovetskogo monastyria XVI v.," Sovetskaia Arkhitektura, (1977)4:306-13.

25 Skopin and Shchennikova, Arkhitekturno-khudozhestvennyi ansambl, 19; and Skopin, Na Solovetskikh ostrovakh, 48-49.

26 The relics were removed to Moscow after a visit to the Solovetskii Monastery by metropolitan Nikon of Novgorod in 1652. This action was taken with the consent and encouragement of tsar Aleksei Mikhailovich. Soon after the arrival of the metropolitan in Moscow, with the relics, Nikon was elevated to patriarch of all Russia. His taking of the relics, although sanctioned by the tsar, offended many at the monastery, and it has been mentioned as one of the contributing factors to the seven-year "Solovetskii Siege" (Solovetskoe sidenie;1668-1676) in defense of the Old Belief. On the removal of the relics, see I. Ia. Syrtsov, Vozmushchenie Solovetskikh monakhov-staroobriadtsev v XVII veke (Kostroma, 1888), 16-17; and Likhachev, "Solovki," 21-22. Fragments of the relics of Filipp remained at the monastery, where they were kept in a framed shrine ( $\underline{\text { raka) }}$ in the Transfiguration Church. See Skopin, Na Solovetskikh ostrovakh, 50. More generally on Nikon's conflict with the monastery, see Georg Michels, "The Solovki Uprising: Religion and Revolt in Northern Russia," Russian Review, 51 (1991): 1-15.

27 For a more detailed analysis of the vaulting system and its relation to Novgorod predecessors, see Petrov, "Spaso-Preobrazhenskii sobor," 199; and Batalov, Moskovskoe kamennoe zodchestvo, 199-200.

28 Those arguing for the existence of an original extended tower include M. V. Shchepkina, "Solovetskii monastyr' v izobrazhenii miniatiury XVI veka," in I. A. Kazus', ed., Solovetskii monastyr'. Iz arkhiva arkhitektora-restavratora P. D. Baranovskogo, vol. 1 (Moscow, 1997), 61. Until its recent publication Shchepkina's article, written in 1954 and related to her candidate's dissertation on Tsarskie litsevye rukopisi (1945), existed in a manuscript held at the State Museum of Architecture, Moscow. Shchepkina's position on the existence of the shatior is fully supported by Il'in, Russkoe shatrovoe zodchestvo, 101-02. See also S. V. Beresh "Evoliutsiia oblika Solovetskogo monastyria po ego izobrazheniiam," in Likhachev, ed., Arkhitekturno-khudozhestvennye pamiatniki, 210-11. A more skeptical position is taken in O. D. Savitskaia, "Nekotorye cherty severnogo zodchestva na primere arkhitekturnykh pamiatnikov Solovetskogo monastyria," Arkhitekturnoe nasledstvo, 21(1973):60-68; and the same author's "Arkhitektura Solovetskogo monastyria," 64-66.

More generally on problems of iconographic representation of the Solovetskii monastery, see A. G. Mel'nik, "O nekotorykh priemakh transformatsii arkhitketury Solovetskogo monastyria v trekh eto izobrazheniiakh kontsa XVI-nachala 
XVII v.," in Popova, ed., Pamiatniki arkhitektury, 218-32; and M. I. Mil'chik, "Arkhitekturnyi ansambl' Solovetskogo monastyria v pamiatnikakh drevnerusskoi zhivopisi," in Likhachev, ed., Arkhitekturno-khudozhestvennye pamiatniki, 233-67.

29 On these two monuments, see Brumfield, History, 114-19, 122-29.

30 See Beresh "Evoliutsiia oblika," 210-11.

31 For a detailed account of Baranovskii's work at Solovki, with a large selection of photographs and drawings, see Kazus', ed., Solovetskii monastyr', 67-130.

32 Baranovskii's opposition was stated in a manuscript response (also held in the State Museum of Architecture) to Shchepkina's paper. It has now been published as: "Otzyv P. D. Baranovskogo o stat'e M. V. Shchepkinoi 'Solovetskii monastyr' v izobrazhenii miniatiury XVI veka'. 15.X.1954 g.," in Kazus', ed., Solovetskii monastyr', 49-55. This position is shared by: Mel'nik, "O nekotorykh priemakh," 228; and V. A. Burov, "Issledovatel' Solovetskogo zodchestva P. D. Baranovskii na Solovkakh (1922, 1923 gg.)," in Kazus', ed., Solovetskii monastyr', 19.

33 See Mel'nik, "O nekotorykh priemakh," 227.

34 For further discussion of the drum and its possible precursors in both Novgorod and Moscow, see Petrov, "Spaso-Preobrazhenskii sobor," 197, 208-10. Petrov argues that without the discovery of new documents, the dispute over the height of the original form is probably irresolvable.

35 On seventeeth-century frescoes in the church, see T. M. Kol'tsova, Severnye ikonopistsy (Arkhangel'sk, 1998), 11. For a view of nineteenth-century frescoes fragments (since removed) that had survived the 1923 fire, see Likhachev, ed., Arkhitekturno-khudozhestvennye pamiatniki, plates 20,23.

36 For brief commentary on the structure of the corner chapels and their relation to Novgorod architecture, see Petrov, "Spaso-Preobrazhenskii sobor Solovetskogo monastyria v ego otnoshenii k novgorodskoi arkhitekture pervoi pol. XVI v.”, in Martynov, ed., Solovetskii Sbornik, 46. See also Batalov, Moskovskoe kamennoe zodchestvo, 127.

37 For further discussion of the arcades and the roofline (with suggestions of Novgorod prototypes), see Petrov "SpasoPreobrazhenskii sobor," in Martynov, ed., Solovetskii Sbornik, 49-50, 52.

38 A number of studies have noted analogies between the form of the Transfiguration Church and the concept of mnogoprestol'nost' (multiple altars) in sixteenth-century church architecture. An extensive discussion of this question is presented in A. L. Batalov, "Ideia mnogoprestol'nosti v moskovskom kamennom zodchestve serediny-vtoroi poloviny XVI v." in A. L. Batalov, ed., Russkoe iskusstvo pozdnego srednevekov'ia (Moscow, 1993), 103-41. This author is not persuaded by Batalov's reasons for assigning a later date to the Diakovo church. See also Batalov, Moskovskoe kamennoe zodchestvo, 132, 142.

39 See Skopin, Na Solovetskikh ostrovakh, 50; and Likhachev, "Solovki," 21.

40 Savitskaia, "Arkhitektura Solovetskogo monastyria," 74, 76.

41 On the razing of the Nicholas Church, see Skopin, Na Solovetskikh ostrovakh, 53.

42 On the defensive measures of 1578-1579 see Likhachev, "Solovki," 22.

43 On the construction of the monastery walls, see Savitskaia, "Arkhitektura Solovetskogo monastyria," 77-83; and V. V. Kostochkin, "Novye dannye o stenakh i bashniakh Solovetskogo monastyria," Arkhitekturnoe nasledstvo, 20(1972):3338. It should be noted that during this same period, and for reasons related to the same military and economic strategy, the settlement that would eventually be known as Arkhangel'sk was founded in 1584 at the site of the Monastery of the Archangel Michael near the mouth of the Northern Dvina.

44 For a detailed study of the monk Trifon and his role in the construction of the walls, see V. A. Burov and V. V. Skopin, "O vremeni stroitel'stva kreposti Solovetskogo monastyria i ee zodchem monakhe Trifone," in V. P. Vygolov, ed., Pamiatniki russkoi arkhitektury i monumental'nogo iskusstva (Moscow, 1985), 58-70, with specific references to Ivan Mikhailov of Vologda on pages 69-70. See also Skopin, Na Solovetskikh ostrovakh, 65.

45 See T. M. Kol'tsova, "Pomorskie ikonopistsy Chalkovy," in Narodnaia kul'tura Russkogo Severa (Arkhangel'sk, 1997), 183-84. On the monastery's role as a center of learning, see S. A. Semiachko, ed., Knizhnye tsentry Drevnei Rusi: Solovetskii monastyr' (Saint Petersburg, 2001).

46 See A. M. Borisov, Khoziaistvo Solovetskogo monastyria i bor'ba krest'ian s severnymi monastyriami v XVI-XVII vekakh (Petrozavodsk, 1966). See also A. A. Savich, Solovetskaia votchina XV-XVII v. (Opyt izucheniia khoziaistva i sotsial'nykh otnoshenii no krainem russkom severe $v$ drevnei Rusi (Perm, 1927). The range of the monastery's economic interests during the late sixteenth century is graphically illustrated by the documents in I. Z. Liberzon, ed., Akty Solovetskogo monastyria, 1572-1584 gg. (Leningrad, 1990).

47 Records of hiring and payment, with reference to archival sources, are presented in Skopin and Shchennikova, Arkhitekturno-khudozhestvennyi ansambl, 52.

48 Likhachev, "Solovki," 23-24.

49 For written sources on the final phase of construction, see Burov and Skopin, "O vremeni stroitel'stva," 63-64.

50 On the Annuciation Church, see Skopin, Na Solovetskikh ostrovakh, 69. See also Savitskaia, "Arkhitektura Solovetskogo monastyria," 76; and Skopin and Shchennikova, Arkhitekturno-khudozhestvennyi ansambl, 55, 66. The protective role bestowed upon gate churches is discussed in V. P. Vygolov, Arkhitektura Moskovskoi Rusi serediny XV veka (Moscow, 1988), 156-58.

51 On the main gallery passage, see Savitskaia, "Arkhitektura Solovetskogo monastyria," 56, 76. 


\title{
Архитектурный ансамбль шестнадцатого века \\ в Спасо-Преображенском \\ Соловецком монастыре
}

\author{
У.К. Брумфильд \\ Университет Тулейн \\ Новый Орлеан, Луизиана, США
}

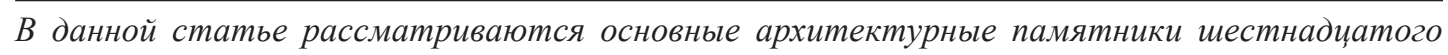
века в Соловецком монастыре. Особое внимание уделено Спасо-Преображенскому собору. Благодаря трудам исключительно одаренного и активного игумена Филиппа во второй половине шестнадцатого века монастырь получил технические и физические ресурсы, необходимые для инициирования крупных строительных проектов. Истоки этих необыкновенных архитектурных достижений можно отнести к культурно и политически сложной «триаде», образованной Новгородской епархией, московским двором и важными монашескими иентрами северной русской культуры. Несмотря на то что монастырь поражает своей уникальностью, многие из архитектурных элементов можно обнаружить у предшественников в Новгороде или Москве. В статье и сопровождающих фотографиях (на основе полевых исследований автора) определяются архитектурные формы, их возможное происхождение и исторический контекст.

Ключевые слова: Спасо-Преображенский Соловеикий монастырь, русская церковная архитектура XVI века, Новгород, Москва, Иван IV (Грозный), Белое море, Филипп (Кольчшев), Св. Зосима, Св. Савватий, Ливонская война .

Научная специальность: 24.00.01 - теория и история культуры. 